\title{
Eruption dynamics of pleistocene maars and tuff rings from the Azrou- Timahdite district (Middle Atlas, northern Morocco) and its relevance to environmental changes and ground water table characteristics
}

\author{
Hicham El Messbahi ${ }^{\mathrm{a}, \mathrm{b}}$, Jean-Marie Dautria ${ }^{\mathrm{b}, *}$, Hervé Jourde $^{\mathrm{c}}$, Philippe Munch $^{\mathrm{b}}$, Olivier Alard ${ }^{\mathrm{b}}$, \\ Jean-Louis Bodinier ${ }^{\mathrm{b}, \mathrm{d}}$, Houssa Ouali ${ }^{\mathrm{e}}$ \\ ${ }^{a}$ Département de Géologie, Faculté Polydisciplinaire, Université Sidi Mohamed ben Abdallah, Route d'Oujda, B.P. 1223, Taza, Morocco \\ ${ }^{\mathrm{b}}$ Géosciences Montpellier, Université de Montpellier \& CNRS, Campus Triolet, cc 060, Place Eugène Bataillon, 34095, Montpellier, cedex 5, France \\ ${ }^{\mathrm{c}}$ Hydrosciences Montpellier, Université de Montpellier, CNRS \& IRD, 300 Avenue du Professeur Emile Jeanbrau, 34090, Montpellier, France \\ ${ }^{\mathrm{d}}$ Department of Geology \& Sustainable Mining, Mohammed VI Polytechnic University, Lot 660, Hay Moulay Rachid, 43150, Benguerir, Morocco \\ ${ }^{\mathrm{e}}$ Département de Géologie, Faculté des Sciences, Université Moulay Idriss, B.P. 1120, Av. Zitoune, Meknès, Morocco
}

\begin{abstract}
A B S T R A C T
The small $\left(\approx 500 \mathrm{~km}^{2}\right)$ Azrou-Timahdite basaltic area (Middle Atlas Magmatic Province, Northern Morocco) lies on a Lias (200-180 Ma) karst plateau of medium altitude (between 1,750 and 1,950 m). This area includes 23 small-sized Early Pleistocene (2.5-0.8 Ma) scoria cones and 30 Middle Pleistocene (around 0.6-0.5 Ma) hydrovolcanic edifices. The Pleistocene was a period of strong climatic instability in North Africa: three peaks of aridity would have occurred near 2.8 Ma, 1.7 Ma and 1.0 Ma (DeMenocal, 2004), but the period between 500 and 650 ka would belong to a predominantly wet stage (Jimenez et al., 2010). The scoria cones of the AzrouTimahdite area would therefore formed when the climate was dry and the hydrovolcanic edifices when it was wet. The hydrovolcanic edifices of the Azrou-Timahdite area are peculiarly interesting because they display an exceptional diversity in terms of morphologies and ejecta deposits which can be only explained by interaction of magma with variable amounts of water, sometimes even during a single eruptive event. The karst regions like the Middle Atlas Plateau are very sensitive to fluctuations in rainfall and during a wet climatic episode the deep karst is permanently saturated with water while the epikarst has degrees of saturation that vary with the topography. Our study suggests that the diversity of hydrovolcanic dynamics in the Azrou-Timahdite area could be linked not only to the degree of saturation of the epikarst but also to the thickness of the transmission zone separating the deep water-saturated karst and the epikarst which also depends on the topographic position of the eruptive sites.
\end{abstract}

\section{Introduction}

In this paper, we focus on a set of hydrovolcanic edifices from a small basaltic area $\left(\approx 500 \mathrm{~km}^{2}\right)$ situated between the towns of Azrou and Timahdite (Northern Morocco) (Fig. 1b) and which belongs to the Magmatic Middle Atlas (MA) Province (Fig. 1a). These edifices, scattered among small scoria cones and basaltic lava flows (Figs. 1c and 2), are peculiarly interesting because they display an exceptional diversity with respect to morphologies and ejecta types, sometimes even within a single edifice.

Hydrovolcanic eruptions have been described for more than fifty years (i.e. Thorarinsson et al., 1964) in many places in the world. Although their dynamics and ejecta deposit mechanisms are now well documented (e.g., Heiken, 1974; Fisher, 1979; Wohletz and McQueen, 1984; Fisher and Schmincke, 1984; Lorenz, 1986; Lorenz, 1987; Sohn and Chough, 1989; Németh et al., 2001; Brand and White, 2007, 2009; Nemeth et al., 2012; Agustin-Flores et al., 2014; Agustin-Flores et al., 2015, Németh and Szabolcs, 2020), they are still not fully understood. We know that, in continental areas such as the MA, hydrovolcanic eruptions result from explosive sub-aerial activity related to the interaction between a rising magma and water, either trapped at depth (aquifer) or stored at the surface (pool, marsh, river, etc.). In addition to their specific structures, ejecta are characterized by their low juvenile pyroclast content in contrast with the purely magmatic ejecta occurring in scoria cones. Purely phreatic eruptions do not even contain any juvenile magma (Cas and Wright, 1988). Two types of continental

\footnotetext{
* Corresponding author.

E-mail address: jean-marie.dautria@orange.fr (J.-M. Dautria)
} 

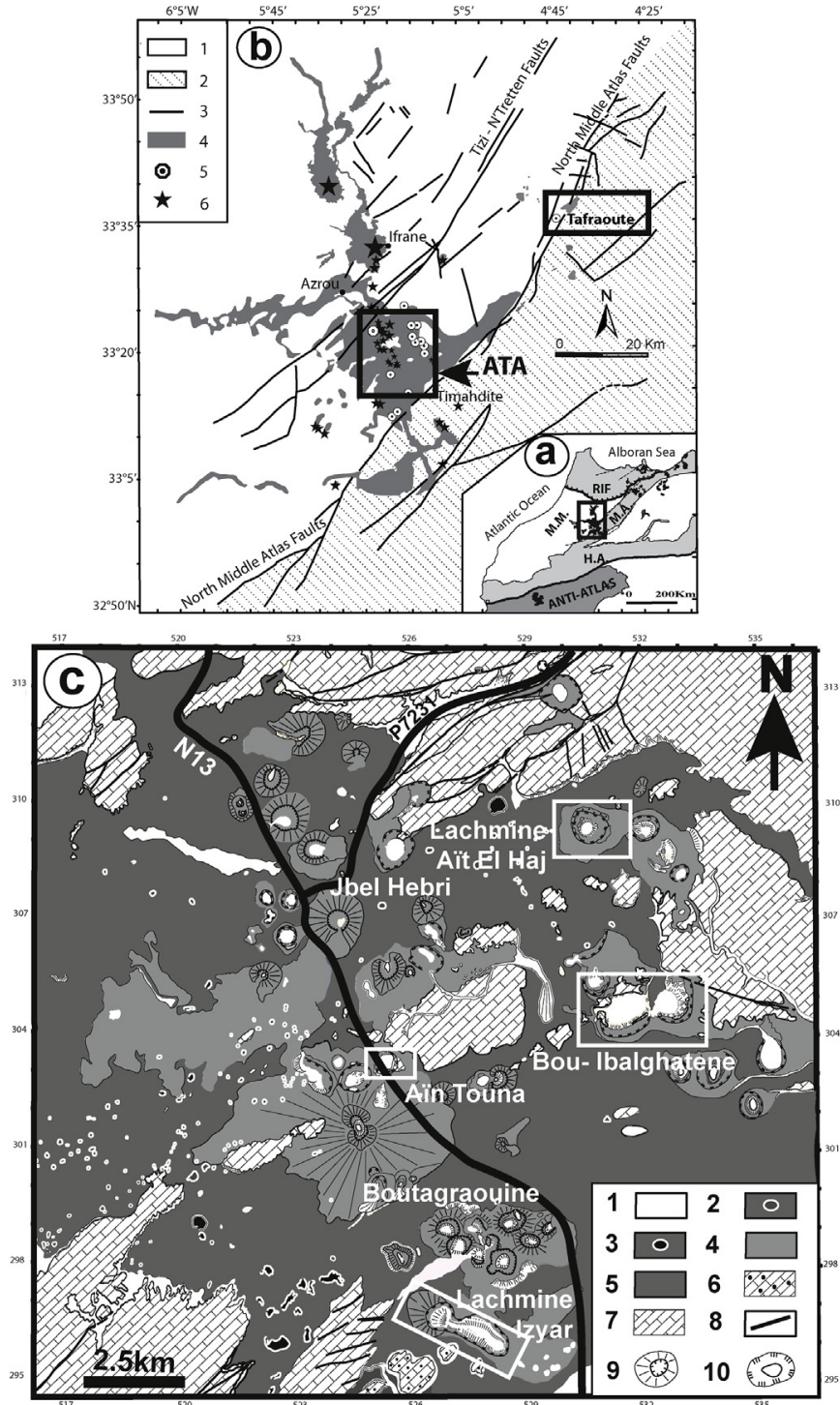

Fig. 1. (a) Simplified structural map of Northern and Central Morocco showing the location of the Middle Atlas Volcanic District (open square) with regards to the major tectonic units (H.A.: High Atlas; M.A.: Middle Atlas; M.M.: Moroccan Meseta. (b) Simplified geological map of the Middle Atlas Volcanic District (modified from El Azzouzi et al., 2010) showing the location of studied sectors (open squares). ATA = Azrou-Timahdite Area; (1) Unfolded and (2) folded Liassic limestone; (3) major faults; (4) volcanic cover; (5) hydrovolcanic edifice, (6) Strombolian cones. (c) Geological map of the Azrou-Timahdite Area (modified from the Geological map of Azrou, 1/50,000, Geological Survey of Morocco, 2005); (1) Quaternary deposits; (2) dry and (3) flooded collapsed cavities resulting from dissolution of substratum; (4) tephra; (5) basalt flows; (6) Lower Cretaceous limestone; (7) Liassic limestone; (8) major faults (9) Strombolian cones; (10) hydrovolcanic edifices. Open squares: studied edifices.

hydrovolcanic edifices are distinguished: "maars" and "tuff rings". Maars form when the rising magma interacts with water trapped at depth but in moderate quantities. In this case, the water is entirely vaporized. Typically, maars are comprised of craters with diameters of a few hundreds meters but not larger than $3 \mathrm{~km}$ (White and Ross, 2011) and relatively great depths (but generally less than $100 \mathrm{~m}$ ), with subvertical edges and flat floors that are always below the level of the surrounding terrains. These craters are either completely or partially surrounded by relatively thin (ten to several tens of metres) crescentshaped embankments of bedded ejecta with sub-vertical inner slopes and gentle outer slopes. In contrast, tuff rings are formed when rising magma interacts with abundant water close to or at the ground surface.
In this second case, the water is not entirely vaporized and therefore part of it remains in a liquid state. The associated craters are larger and shallower than maars and often even their floors are at the level of the surrounding terrains. Ejecta are generally richer in juvenile pyroclasts than maars and the inner and outer sides of embankments display a low and approximately equal slope.

The volcanoes of the Azrou-Timahdite Area (ATA) are all of Pleistocene age. The Pleistocene was a period of strong climatic instability in North Africa: dry and wet stages followed each another while glacial and interglacial stages alternated in Europe (Lisiecki and Raymo, 2007). The exact age and duration of the dry and wet stages are still topics of debate (Jimenez, 2010; Grant et al., 2017). Although still poorly constrained from an age point of view, the Pleistocene volcanic activity in the Azrou-Timahdite area (ATA) has been long enough [between 2.5 and 0.5 Ma according to Harmand and Cantagrel (1984) and El Azzouzi et al. (2010)] to encompass several dry and wet phases.

The ATA hydrovolcanic edifices are also interesting because they lye on a karst plateau of medium altitude (between 1,750 and 1,950 m). The karst regions are very sensitive to fluctuations in rainfall (Jacob et al., 2008), and therefore to climate variations. Such variations result in changes in both the water table depth of the perched aquifer located in the epikarst (Williams, 2008) and in the water table depth of underneath karst aquifer. If a volcanic activity happens in the same time as these climate variations, the hydrodynamic changes in the karst must have an impact on the volcanic dynamics. This has already been emphasized in the Miocene to Pliocene Bakony-Balaton Highland volcanic field in Hungary (Németh et al., 2001) and in a Plio-Pleistocene district of Central Mexico (Aranda Gomez and Luhr, 1996).

The aim of this article is twofold: to highlight the peculiarities of the ATA hydrovolcanic eruptions and try to relate them with the hydrodynamic changes into the regional karst subjected to the Pleistocene climatic instability.

\section{Geological framework}

Northern Morocco has a very complex geology because of its peculiar setting at the triple junction between the Atlantic Ocean, the Western Mediterranean and the West African Craton (Frison de Lamotte et al., 2008 and references therein). It includes three sub-parallel Cenozoic Alpine ranges from north to south, respectively: the Rif, the Middle Atlas (MA) and the High Atlas (HA) (Fig. 1a). Magmatic activity took place between the Upper Cretaceous and the Pleistocene in the HA and MA. The uplifting of these two ranges and the associated magmatism are linked to mantle dynamics (Missenard et al., 2006; Duggen et al., 2009; El Messbahi et al., 2015 and references therein).

\subsection{The volcanic district of Middle Atlas}

The MA Volcanic district (Fig. 1a and b) is the youngest in the Atlas Magmatic Province. According to Harmand and Cantagrel (1984), El Azzouzi et al. (2010) and Kharbouch (2010), the oldest volcanic rocks are Eocene in age $(\approx 34 \mathrm{Ma})$ and, at this time, their vents were all located in the southernmost part of the district along the High Atlas front (Fig. 1a). During the Mid- and Late Miocene (between 15 and $6 \mathrm{Ma}$ ), the magmatic activity shifted northward and the new emission points were distributed throughout the entire MA (Fig. 1a and b). Finally, during the Upper Pliocene and Pleistocene, the volcanic activity migrated to the north. Close to 70 volcanic edifices -20 previously identified as maars and 50 as Strombolian scoria cones - formed in the northern half of the district (Fig. 1b and c and 2). All MA lavas belong to the alkali series (El Azzouzi et al., 2010): nephelinites, basanites, alkali basalts and subalkali basalts. Differentiated lavas are lacking. The origin of this magmatism (El Azzouzi et al., 2010; Bosch et al., 2014) and the nature of the mantle from which they derived (El Messbahi et al., 2015, and references therein) have been widely discussed. 


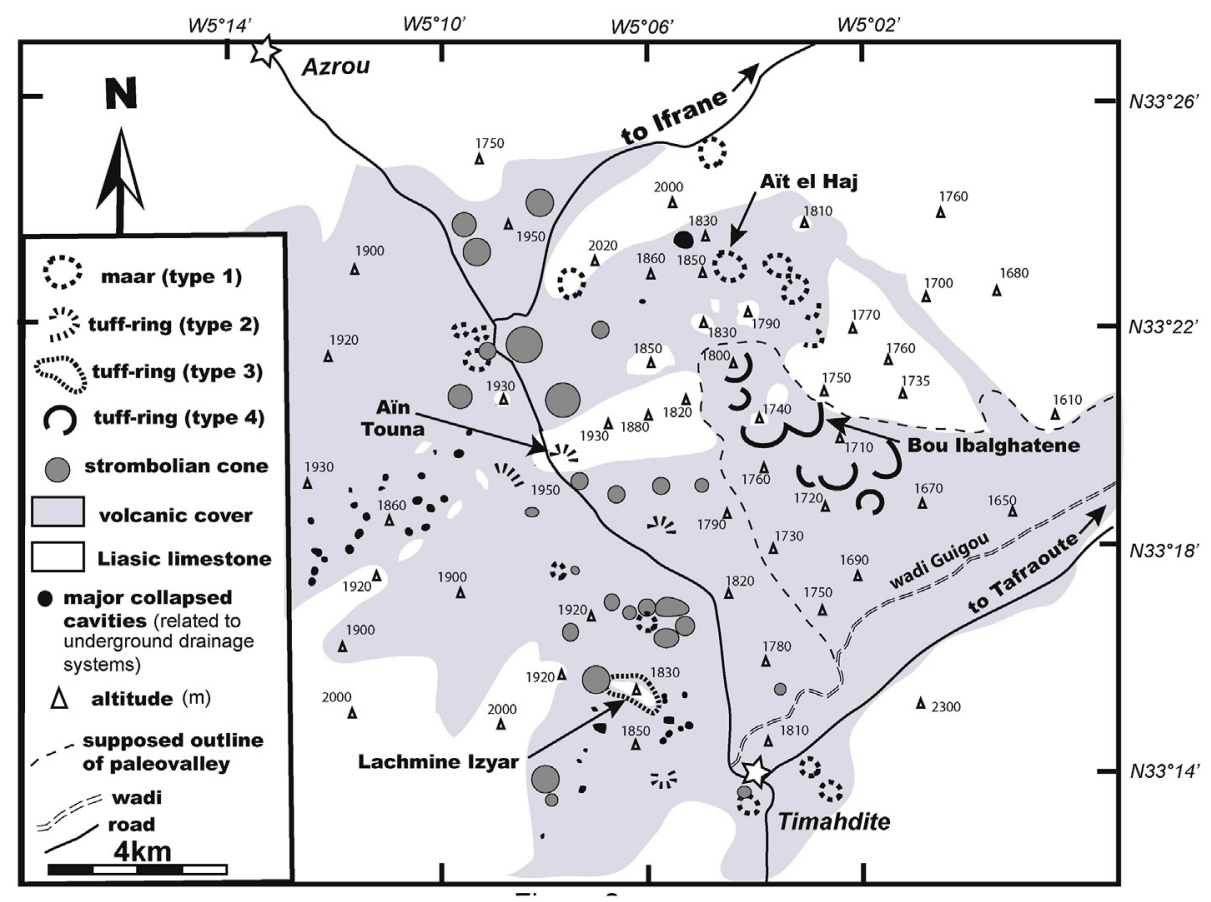

Fig. 2. Distribution through the Azrou-Timahdite area of the four types of hydrovolcanic edifice defined in the text in relation to the elevations of the plateau surface.

\subsection{The Azrou-Timahdite basaltic area}

As shown in Fig. 1b, this area although small $\left(\approx 500 \mathrm{~km}^{2}\right)$, is the largest volcanic rock covered surface in the MA magmatic district. Approximately $75 \%$ of the recent scoria cones and all hydrovolcanic edifices are grouped here (Figs. 1C and 2). This area lies on a plateau (Tabular MA) of medium altitude (between 1,750 and 1,950 m), which is bounded to the south by reliefs around $2,300 \mathrm{~m}$ (Fig. 2) corresponding to the folded MA thrust-front (Fig. 1b and c). The Tabular MA essentially consists of up to $150 \mathrm{~m}$ thick, sub-horizontal or gently undulating and more or less dolomitic Lias limestones, that lie on Upper Triassic reddish shales and evaporites (Charrières, 1985; El Arabi, 1987; Fedan, 1988; Fedan et al., 1989). This plateau as a whole shows a karst morphology comprising intermittent streams, dolines, poljes, sinkholes and shafts. Its southwards subsurface drainage system feeds the perennial Wadi Guigou River that runs parallel to the folded MA thrustfront (Figs. 1b and 2).

The Tabular MA Liasic limestones are exposed on the surface since at least the Upper Jurassic or Lower Cretaceous, which corresponds to the time when the karstogenesis started. Moreover, during the whole Cretaceous and Lower Cenozoic, they were confined in a tectonic transpressive corridor, approximately $30 \mathrm{~km}$ wide, between two active major regional thrusts (the NMAF to the south and the Tizi-n Tretten Fault to the north, Fig. 1b and c). This probably resulted in a karstogenesis continuation that was synchronous with both the fracturing and deformation of the limestones. Moreover, the Miocene uplift of the MA favoured the deepening of the karst drainage. The current landscape resulting from this evolution is a smoothed karst landscape where vast shallow poljes (often partly filled with recent volcanic deposits) alternate with small linear and rounded limestone reliefs.

The petrology of the ATA lavas is quite well known (see above), however very little attention has been to the volcanology with exception of some rare recent studies (Lakroud et al., 2019; Abdelmounji et al., 2019). As shown in Figs. 1c and 2, 23 scoria cones and 30 hydrovolcanic edifices (maars and tuff rings) are scattered throughout the ATA lava fields. All scoria cones are relatively small sized $(1,200 \mathrm{~m}$ maximum diameter, $160 \mathrm{~m}$ maximum height for Jbel Hebri, Figs. 1c and 2) and they emitted one single lava flow. Many of them display breached craters. They are all monogenetic in the sense of Németh and Kereszturi (2015) and Smith and Nemeth (2017): small volume edifices formed through a "one shot eruptive event". However most of them have thin phreatomagmatic deposits (between several tens of $\mathrm{cm}$ and a few $\mathrm{m}$ ) at their base with characteristic dry base surge structures. Such a succession was already documented from similar small cones from Saudi Arabia (Murcia et al., 2015). Only one edifice (Jbel Bou Tagraouine, $6 \mathrm{~km}$ north of Timahdite, Fig. 1c) shows more complex activity evoking a small fissure eruption: this edifice, $3.5 \mathrm{~km}$ long, up to $2 \mathrm{~km}$ wide and $140 \mathrm{~m}$ high, is formed by the coalescence of eight vents that are roughly aligned following an E-W trend. The hydrovolcanic edifices have very variable sizes and morphologies and their detailed study will be presented in paragraph 3 .

The projections are concentrated around the vents and the ATA plateau is largely covered by lava, usually by one flow, two at the most. Thus, the volcanic cover is thin enough (most often less than $5 \mathrm{~m}$ ) to allow the outcropping of limestone substratum in many places, even in the zones that seem the most volcanized from a cartographic point of view. Consequently, in spite of the relatively large number of emission points and the size of the volcanized surface $\left(\approx 500 \mathrm{~km}^{2}\right)$, we estimate that the volume of lava emitted in the ATA was relatively small (between 2 and $3 \mathrm{~km}^{3}$ ). Another consequence of the thinness of the volcanic cover is the occurrence of small-sized collapsed hollows, crippling many lava flows, especially in the SW and central parts of the area (Figs. 1c and 2). These hollows have diameters of several tens of metres to one hundred metres and depths of several metres, and some of them even form temporary ponds during rainy events. These collapsed areas are clearly the consequence of the dissolution of the underlying limestone (caprock dolines) (Bentayeb and Leclerc, 1977) that obviously continued to proceed under the volcanic cover during the Pleistocene and is probably continuing today. Therefore, their geographical distribution probably highlights the geometry of the underlying karst drainage network (Fig. 2). In addition, many limestone mounds, sometimes large in size (up to $4 \mathrm{~km}$ long), emerge from the volcanic cover (Figs. 1c and 2).

To the NE of Timahdite, there is a slightly depressed and gently sloping zone less than $10 \mathrm{~km}$ long, 2-6 km wide and 30-100 m deep (Fig. 2). This relatively small zone $\left(<20 \mathrm{~km}^{2}\right)$ widens towards the SE 

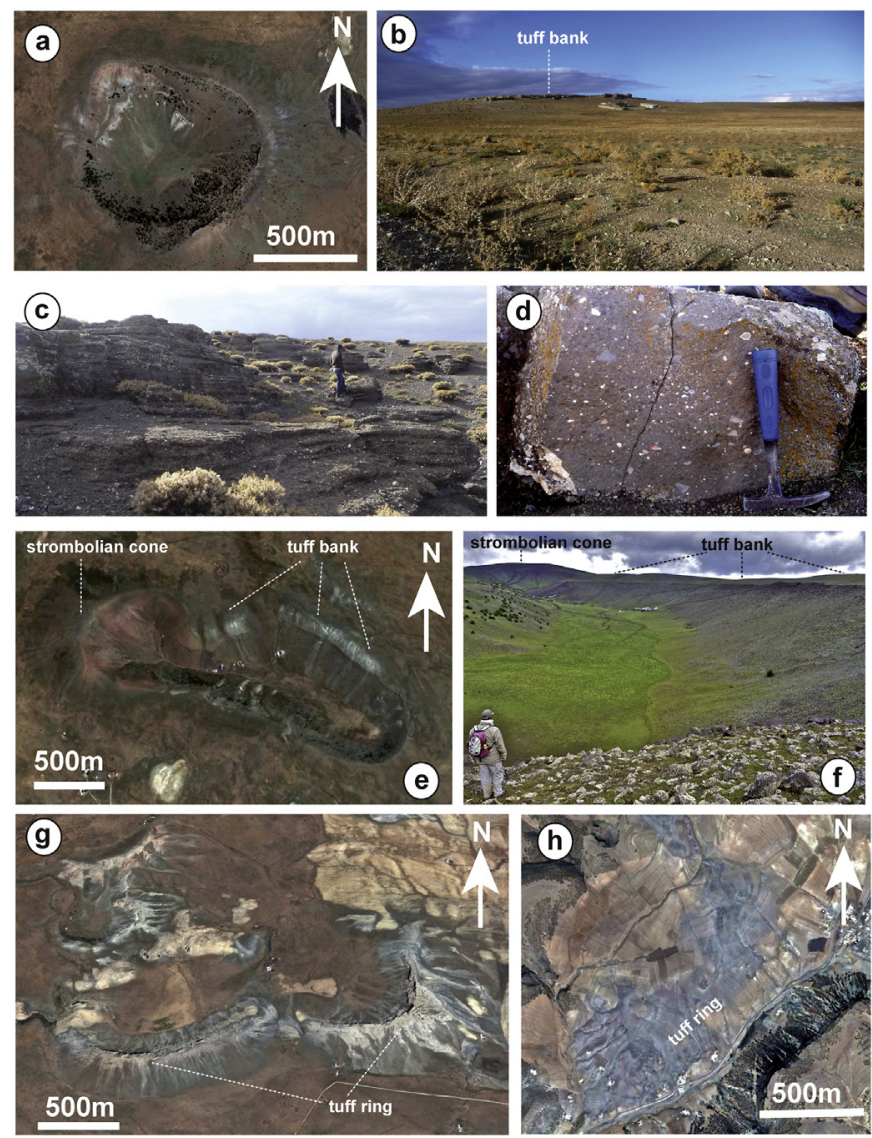

Fig. 3. (a) Satellite vertical image of the Lachmine Ait El Haj maar. (b) The Ain Touna ejecta embankment seen from the southern edge of crater; (c) Bedding in the Ain Touna breccia; (d) Hand-sample of matrix-supported breccia from Ain Touna; (e) Satellite vertical image of the Lachmine Izyar crater; (f) The Lachmine Izyar crater seen from its SE edge; (g) Satellite vertical image of the two coalescent tuff half-rings of Bou Ibalghatene and (h) of the Tafraoute tuffring. All satellite images are from Google Earth, Landsat Copernicus, 12-032017, Digital Globe.

with slowly decreasing altitudes so that it connects to the Wadi Guigou valley. One-third of the ATA hydrovolcanic edifices, including all of the largest ones, are clustered in this area (Fig. 2).

\section{Inventory of the hydrovolcanic edifices in the Azrou-Timahdite} area

Referring only to morphological criteria, the ATA hydrovolcanic edifices can be described as either maars or tuff rings. Whatever the type of edifice, few of them have evolved until a Strombolian activity and none have emitted a lava flow, probably because of the small amount of magma mobilized at each eruption. Although the majority have diameters between 250 and $800 \mathrm{~m}$ and crater depths less than $20 \mathrm{~m}$, several of them display quite large sizes (e.g. $4 \mathrm{~km} \times 2 \mathrm{~km}$ for the Bou Ibalghatene hydrovolcanic complex, Figs. 1c, 2 and $3 g$ ) and one crater even reaches $80 \mathrm{~m}$ (Lachmine Izyar, Figs. 1c, 2, 3e, $3 \mathrm{f}$ and 4.3). The majority of the "small" hydrovolcanic edifices are formed of circular or elliptical flat-bottomed depressions with elevations close to the surrounding plateau (e.g. Aïn Touna, Figs. 1c, 2, 3b and 4.2). In contrast, the largest edifices are always polylobed (e.g. Bou Ibalghatene, Figs. 1c, 2 and $3 g$ ), showing that they result from the coalescence of several centres that were active at the same time. With the current climate (the average precipitation in Timahdite is around $700 \mathrm{~mm} /$ year (El Jihad, 2016), small temporary ponds occupy some craters during the winter and spring (e.g. Bou Ibalghatene). The craters are rimmed, sometimes entirely or most often partially, by linear or crescent-shaped embankments consisting of stratified ejecta, with thicknesses of ten to several tens of metres (up to $50 \mathrm{~m}$ at Bou Ibalghatene, $35 \mathrm{~m}$ at Tafraoute). The ejecta thicknesses decrease quite rapidly outside the crater in such a way that their outer extensions are relatively short (several hundred metres, maximum $800 \mathrm{~m}$ at Bou Ibalghatene, Fig. 3g). With the exception of Lachmine Izyar (Figs. 1c, 2, 3e, 3f and 4.3), ejecta are limited on the crater side by almost vertical and stepped cliffs, when the craters reach the limestone basement, (i.e. Bou Ibalghatene, Tafraoute, Lachmine Ait el Haj, Figs. 1c and 2). In contrast, the outer flanks of the embankments have gentle slopes corresponding approximately to the dips of the ejecta layers (approximately $10^{\circ}$ ). In the case of edifices with shallow craters, the ejecta are generally concentrated on only one edge and they appear as almost linear or slightly curved embankments: they are only several hundred metres long and wide and between ten and $20 \mathrm{~m}$ high, with rounded tops and a low slope for both the inner and outer flanks (e.g. Ain Touna, Figs. 1c, 2, 3b and 4.2). The Lachmine Izyar edifice is paradoxal (Figs. 1c, 2, 3e, f and 4.3): despite having the deepest crater $(80 \mathrm{~m})$ in the area, its embankment of ejecta is linear, relatively thin $(<30 \mathrm{~m})$ and it resembles those described for edifices with shallow craters.

Our field observations led us to distinguish four types of hydrovolcanic edifices in ATA. In the following descriptions, the terms tuff, lapilli-tuff and tuff-breccia are based on Fisher (1966) criteria and the term clast is based on the definition provided by Fisher and Schmincke (1984): all of the rock fragments that are expelled through volcanic vents without reference to an eruptive mechanism or petrographic nature. In the case of the ATA, the clasts are fragments of juvenile magma, earlier volcanic rocks, Liasic limestone and chert. Neither sedimentary rock fragments prior to the Lias nor upper or middle crust fragments have ever been found among the clasts, suggesting that the water interacting with the magma was stored in the same Liasic layers as those surrounding the edifices, therefore at relatively shallow depths (several tens of metres, less than $150 \mathrm{~m}$ ). In contrast, deep crustal granulite and lithospheric mantle peridotite fragments are often present: they correspond to xenoliths entrained by the juvenile basalts ( $\mathrm{El}$ Messbahi et al., 2015 and references therein).

\subsection{Type 1: Lachmine Aït el Haj}

The edifices of Type 1 are characteristic maars. Among the five maars identified here, the Ait El Haj $\left(33^{\circ} 22^{\prime} 53^{\prime \prime} \mathrm{N}-5^{\circ} 04^{\prime} 14\right.$ ”W, Figs. 1c and 2) is the most impressive (Figs. 3a and 4.1). It is one of the few edifices whose the activity ended with a Strombolian episode comprising the edification of a small cone on its NW edge (Fig. 4.1) and the emplacement of a metric basaltic sill inside the SW lower deposits. This edifice overhangs the surrounding basaltic cover of approximately $30 \mathrm{~m}$ and it is close to $1500 \mathrm{~m}$ in diameter. Its crater is circular (diameter of around $500 \mathrm{~m}$ ) and it cuts the limestone basement up to $55 \mathrm{~m}$. It is surrounded by a half-ring of ejecta, between 10 and $50 \mathrm{~m}$ thick and between 200 and $550 \mathrm{~m}$ wide (Fig. 4.1). A picture of its inner NW edge is given in Fig. 5: it provides an overlook of the ejecta series that includes fallout breccia, dry base surge deposits, Strombolian breccia and lapilli-tuff. It is also important to note the occurrence of some mudflow layers, about $50 \mathrm{~cm}$ thick, interstratified with the base surge deposits into the lower and median part of the series. As will be discussed below, the presence of such episodic mudflows suggests that the water supply increased at times during the eruption (Lorenz, 2003). Water may have even invaded the bottom of the crater several times albeit briefly.

\subsection{Type 2: Ain Touna}

The edifices of this type are always difficult to spot in the landscape because of their small topographic imprint. Only three have been clearly identified: they are all grouped in a small area in the centre of the ATA where the volcanic cover is very thin or even lacking. Ain 
Touna ( $35^{\circ} 19^{\prime} 36^{\prime \prime} \mathrm{N}-5^{\circ} 07^{\prime} 38^{\prime \prime} \mathrm{W}$, Figs. $1 \mathrm{c}$ and 2 ) is the best example. Its crater appears as an almost circular depressed zone close to $700 \mathrm{~m}$ in diameter and approximately $5 \mathrm{~m}$ deep compared to the surrounding limestone (Figs. 3b and 4.2). To the north and northwest, a sickleshaped embankment with a rounded top (about $700 \mathrm{~m}$ long, between 100 and $350 \mathrm{~m}$ wide and between 5 and $15 \mathrm{~m}$ high) borders this depression (Figs. 3b and 4.2). To the east and southeast, it is limited by tuffs belonging to a previous scoria cone whose NW flank is partially collapsed (Fig. 4.2). To the east, the ejecta embankment caps lacustrine grey sandy marls, about $3 \mathrm{~m}$ thick, lying on Liasic limestones. These marls display a horizontal stratification underlined by discontinuous horizontal centimetre beds of gravels rich in small basaltic pebbles and by clayish levels with mud cracks at their top. The volcanic ejecta embankment consists of approximately fifty layers (Fig. 3c) of matrixsupported breccia displaying structures varying between mud and debris flows (Fig. 3d). The first layer is the thickest $(\approx 70 \mathrm{~cm})$ and coarsest in the series: it is a debris flow containing limestone and basalt blocks up to $20 \mathrm{~cm}$ in size and gullying the underlying marls on more than $30 \mathrm{~cm}$. The overlying levels have thicknesses comprised between 10 and $40 \mathrm{~cm}$ : the stratification is sub-horizontal and the traces of erosion between them are rather scarce (Fig. 3c). The matrix, which constitutes up to $80 \%$ of breccia, is grey to light brown, argillocalcareous and the clasts are usually small $(\varnothing<5 \mathrm{~cm})$, angular and mostly from surrounding Liasic limestones; the few basaltic clasts present are rather vesicular and altered and they probably come from the scoria cone that borders the crater to the east. Some layers enriched in clasts (up to $80 \%$ ) are present, especially in the middle part and on the top of the series. Many layers display slight graded-bedding: it is generally normal, more rarely inverse. However, many layers (Fig. 3d) have no graded bedding. Many layers show clay concentrations measuring several $\mathrm{cm}$ thick at their tops, probably corresponding to settling levels. These clay levels often show mud cracks, that suggests that the time between the emplacement of 2 successive flows was sufficient (some hours, some days?) to dry up and contract the top walls of flows. Neither bombs nor smaller fragments of juvenile basalt, glassy or not, have been found in the Aïn Touna ejecta.

\subsection{Type 3: Lachmine Izyar}

Lachmine Izyar $\left(33^{\circ} 15^{\prime} 51^{\prime \prime} \mathrm{N}-5^{\circ} 06^{\prime} 12^{\prime \prime} \mathrm{W}\right.$, Figs. $1 \mathrm{c}$ and 2$)$ is the only edifice of this type. The depression assumed to correspond to its crater is the most impressive one of the MA: it has an elliptical shape oriented NE-SW (major axis of $1.4 \mathrm{~km}$ and minor axis of $600 \mathrm{~m}$ ) and its mean depth is around $80 \mathrm{~m}$ (Figs. 3e and f)]. The crater is almost entirely surrounded by a basaltic cliff between 5 (southern edge) and $10 \mathrm{~m}$ (northern edge) high corresponding to one (south) or two (north) previous basaltic flow(s) (Fig. 4.3). Liasic limestones appear under these flows in the inner flanks of the crater to its bottom (Fig. 4.3). A triangular ejecta embankment lying directly on the upper basaltic flows appears on the northern edge of the crater (Fig. 4.3): it is close to $1.5 \mathrm{~km}$ long, $600 \mathrm{~m}$ wide and $30 \mathrm{~m}$ high and it has a rounded top and gentle inner and external slopes. Another embankment appears on the southern edge: it is reduced to less than $5 \mathrm{~m}$ thick, several tens of metres wide and several hundred metres long (Fig. 4.3). To the west, this crater is connected via a narrow valley about $250 \mathrm{~m}$ long to the breached crater of a previous Strombolian cone. This cone is probably the origin of one the two basaltic flow cut by the Lachmine Izyar crater (Fig. 3e and $3 f$ and 4.3).

Unfortunately, the ejecta crops out poorly. A scree covers the foot of the northern embankment: it likely results from in-situ dismantling of a poorly consolidated big block breccia level several metres thick that laid directly on the upper basalt flow, which constitutes the northern edge of the crater (Fig. 3e and $f$ and 4.3). This scree includes angular big blocks (up to $1.5 \mathrm{~m}$ in diameter) of basalt from the underlying flow, decimetric blocks of brownish to reddish lapilli tuffs (probably originating from the neighbouring scoria cone, Fig. 3e and $f$ and 4.3) and of substratum limestone. The matrix of this breccia is preserved only as coating on the surfaces of some blocks: it is argillo-sandy-calcareous and beige in colour. Above this scree, the embankment consists of approximately $25 \mathrm{~m}$ of a finer breccia in layers between 10 and $40 \mathrm{~cm}$ thick that contain basalts and limestones with angular fine- to mediumgrained clasts $(\varnothing<10 \mathrm{~cm}$ ). The relative proportion between the basalt and limestone varies between 10 and 50\% (visual estimation) depending on the layers. The structure of these layers is also variable: it is sometimes powdery, sometimes indurated, sometimes without gradedbedding or with weak normally graded bedding. The matrix is always sandy-argillo-calcareous but its color is variable: whitish to beige, sometimes grey or pinkish. These layers are fairly comparable to those that constitute the Ain Touna embankment. Moreover, as in Ain Touna, these layers do not seem to erode each other. Fig. 6 shows a breccia layer of this type. Slightly cross-bedded muddy layers between 5 and $10 \mathrm{~cm}$ thick and displaying dips parallel to the slope constitute the outer deposits (close to $400 \mathrm{~m}$ wide) on the northern flank. Note that no beds showing a wet or dry base surge structure are interbedded here between the breccia layers, as we shall see in the Type 4 edifices. A rough estimation of the respective crater and tuff embankment volumes shows that the first one is approximately ten times greater than the second one. This suggests that there was a deep depression at the Lachmine Izyar location prior to the hydrovolcanic eruption responsible for the formation of the breccia embankment.

\subsection{Type 4: Bou Ibalghatene-Tafraoute}

Edifices of this type are tuff rings that are always large in diameters $(1-2,5 \mathrm{~km})$ and have the most complex ejecta structure. One dozen has been identified and, except for Tafraoute, which is located $\approx 45 \mathrm{~km} \mathrm{NE}$ of Timahdite (Fig. 1b), all of them are clustered in the small depression described above, which affects the SE quarter of the volcanic cover (Fig. 2). Two of these tuff rings are particularly representative: Bou Ibalghatene and Tafraoute.

The first one $\left(33^{\circ} 20^{\prime} 13^{\prime \prime} \mathrm{N}-05^{\circ} 03^{\prime} 83^{\prime \prime} \mathrm{W}\right)$ is located $11 \mathrm{~km}$ north of Timahdite (Figs. 1c and 2): it is a hydrovolcanic complex including four craters, two large southward and two small northward (Fig. 3g). The two large craters $-1,200 \times 700 \mathrm{~m}$ for the first one, $850 \mathrm{~m}$ in diameter for the second one, 50-80 m deep, including approximately $30 \mathrm{~m}$ excavated within the limestone substratum - are bordered by half-rings of ejecta (Fig. $3 \mathrm{~g}$ ). The western half-ring is elliptical (long axis $\approx 1,700 \mathrm{~m}$, short axis $\approx 1,300 \mathrm{~m}$ ), and the eastern one is circular (about $1,500 \mathrm{~m}$ in diameter) (Fig. 3g). In both cases, the ejecta have thicknesses varying between 20 and $50 \mathrm{~m}$ and they directly overlie the Lias limestones.

Tafraoute $\left(33^{\circ} 31^{\prime} 29^{\prime \prime} \mathrm{N}-4^{\circ} 41^{\prime} 35^{\prime \prime} \mathrm{W}\right.$, Fig. $\left.1 \mathrm{~b}\right)$ is located outside the major volcanic area (Fig. 1b), but it is very similar to Bou Ibalghatene. It includes an elliptical crater (a long axis of $1,000 \mathrm{~m}$ and a short axis of $600 \mathrm{~m}$ ) excavated about $20 \mathrm{~m}$ into the limestones and surrounded to the east and south by a half-ring of ejecta approximately $35 \mathrm{~m}$ thick and between 400 and $600 \mathrm{~m}$ wide (Figs. 3h and 4.4). In addition to its particular geographical position, Tafraoute displays two other peculiarities compared to Bou Ibalghatene: at the same time, it is located above one fault belonging to the NMAF (Fig. 1b) and above the limit between two very different Liasic lithologic levels, white chert-rich limestones and grey impervious marls (Fig. 4.4). A polje roughly $2 \mathrm{~km}$ wide and $5 \mathrm{~km}$ long developed at this location: it has a ponor to the north and the volcanic complex occupies the bottom of its central part.

The Bou Ibalghatene and Tafraoute ejecta, as well as those of all edifices belonging to group 4, show that the deposits are different from those described for the three preceding types: they are stratified but the layers are very variable in terms of thickness (ranging from a few $\mathrm{cm}$ up to $1.5 \mathrm{~m}$ ), bedding features and grain size. However, irrespective of the thicknesses and structures, the matrix is always sandy-argillo-carbonated, and Liasic limestone clasts measuring several $\mathrm{mm}$ to $30 \mathrm{~cm}$ are always present in large amounts (up to $75 \%$ ). Non-vesicular to slightly vesicular basaltic fragments are also present in variable amounts, 
generally between $25 \%$ and $50 \%$ (visual estimate): they are also angular, with diameters comparable to the limestone fragments. While the biggest basaltic fragments have sometimes have typical "cauliflower" shapes, the smallest are glassy and partly palagonitized. Some rare levels contain up to $90 \%$ juvenile pyroclasts. Lower crust and lithospheric mantle xenoliths, with or without basaltic crust, also occur: in some cases, their sizes can reach several tens of $\mathrm{cm}$ (El Messbahi et al., 2015 and references therein).

In spite of the large size of the tuff rings, the volumes of lava emitted by Bou Ibalghatene and Tafraoute - basanites in both cases - seem very small (probably less than $0.05 \mathrm{~km}^{3}$, following basic geometry considerations). Neither of the two edifices displays any traces of Strombolian activity or lava intrusion.

Two types of deposits have been distinguished in the field:

- The first one corresponds to a series of thin layers (always less than $30 \mathrm{~cm}$ thick, often only a few $\mathrm{cm}$ ) of tuff showing typical base surge structures indicative for variable explosive energy. In some coarser layers, "impact sags" are observed under the largest blocks, giving them an obvious ballistic origin.

- The second type corresponds to thick layers (several tens $\mathrm{cm}$ up to $1.5 \mathrm{~m}$ ) of matrix-supported breccia with compositions evolving between mud and debris flows. They contain blocks of the same nature as those of the surge deposits but with generally larger sizes. Here, impact sags are totally lacking under the biggest blocks, but, in contrast, muddy settling deposits with desiccation cracks are almost always observed at their tops.

In both Bou Ibalghatene and Tafraoute, layers with a "base surge" texture are generally more abundant in the lower part of the tuff ring, while the matrix-supported breccia layers are more abundant in the higher part. Nevertheless, thin series of tuffs interpreted to have a base surge origin, are interbedded with breccia layers up to the top of the ring. In order to illustrate the deposit conditions for the type 4 ejecta, we present two logs (Figs. 7 and 7 continued) representing the complete and continuous section $(\approx 25 \mathrm{~m})$ of the SW inner edge of the Tafraoute tuff ring (the location of the section is plotted in Fig. 4.4). This ring is described in detail in Appendix 1 of supplementary material.

\section{New precision on the age of the Azrou-Timahdite hydrovolcanism}

Our field observations clearly show that the ATA hydrovolcanic activity is, as a whole, more recent than the Strombolian activity. Hydrovolcanic craters cut the lava flows of the neighbouring scoria cones and their ejecta cover these flows at the same time (e.g. Bou Ibalghatene, Lachine Ait el Hadj, Lachmine Izyar; Fig. 4). The hydrovolcanic activity could even correspond to the latest eruptive event in the MA.

The age of the ATA Strombolian activity is quite well documented. A dozen flows have been dated using the $\mathrm{K}-\mathrm{Ar}$ method on whole rock (Harmand and Cantagrel, 1984; El Azzouzi et al., 2010): the ages range between 0.8 and $2.6 \mathrm{Ma}$

Only one hydrovolcanic edifice, the Ait El Haj maar described above, has been dated up until now: $500 \pm 150$ ka (Harmand and Cantagrel, 1984). It should be noted that this age is significantly younger than the Strombolian activity. To determine the age of the ATA hydrovolcanism, it was crucial to measure the age of at least one additional edifice. For this purpose, we carried out a new dating at Tafraoute (Fig. 1b), one of the largest and most interesting hydrovolcanic edifices in the region. The age was measured using the ${ }^{40} \mathrm{Ar} /{ }^{39} \mathrm{Ar}$ stepheating method on glass fragments $(0.1<\varnothing<0.2 \mathrm{~mm})$ from the central part of a juvenile basalt cauliflower bomb (around $15 \mathrm{~cm}$ in diameter) collected in a base surge lapilli-tuff belonging to the middle part of the ejecta series overhanging the crater to the east (Fig. 4.4). The choice of such a bomb was made in order to ensure that the dating

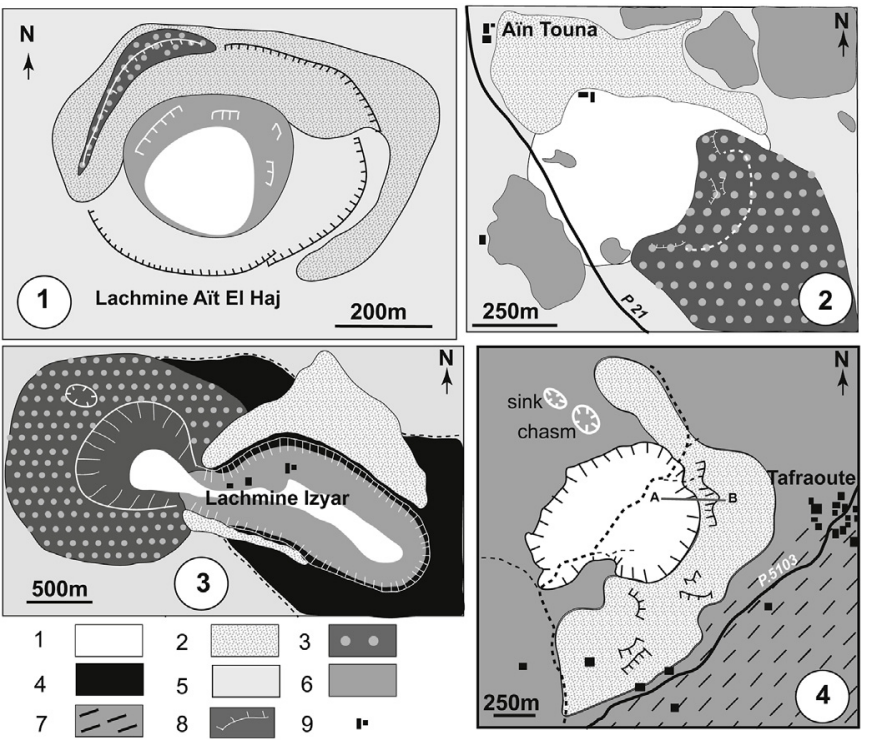

Fig. 4. Simplified geological maps of the hydrovolcanic edifices taken as example for each of the 4 types of hydrovolcanic edifice (see text); (1) Quaternary deposits; (2) Hydrovolcanic tuff; (3) Strombolian ejecta; (4) basaltic flow from the Strombolian cone W to Lachmine Izyar; (5) Plio-Quaternary basaltic cover; (6) Lower Liassic karstic limestone ( \pm cherts); (7) Upper Liassic marl; (8) Cliff.

represents the age of the eruption (Balogh and Nemeth 2005). This sample yielded a plateau age of $610 \pm 30$ ka (error given at 2 s) corresponding to $100 \%$ of the ${ }^{39} \mathrm{Ar}$ released and a concordant inverse isochron age of $540 \pm 90$ ka with a Mean Square Weighted Deviation of 0.83 and an initial ${ }^{40} \mathrm{Ar} /{ }^{36} \mathrm{Ar}$ ratio of $300.5 \pm 7.1$, which is undistinguishable from the atmospheric ratio $\left({ }^{40} \mathrm{Ar} /{ }^{39} \mathrm{Ar}\right.$ data table and plateau age figure are given in Appendix 2 of Supplementary Material). We retain the plateau age as the best estimate. This age $(610 \pm 30 \mathrm{ka})$ is slightly older, yet within error, than that of Lachmine Ait el Hadj $(500 \pm 150 \mathrm{ka})$, but it confirms that the hydrovolcanic activity in the ATA is more recent than the Strombolian one.

\section{Discussion}

\subsection{Volcanic dynamism and paleoclimate}

Strombolian activity developed in the ATA during the Lower Pleistocene (between 2.6 and $0.8 \mathrm{Ma}$ ). The lack or thinness of the pheatomagmatic deposits under the Strombolian tuffs suggests that the underlying karst was at that time slightly supplied by surface water: the climate of the MA was therefore rather dry. In subtropical Africa, three peaks of aridity would have occurred near $2.8 \mathrm{Ma}, 1.7 \mathrm{Ma}$ and 1.0 Ma, coinciding with the onset and intensification of high-latitude glacial cycles (DeMenocal, 2004). According to Grant et al. (2017), the periods between 2.5 and $2.35 \mathrm{Ma}, 2.1$ and 1.95 Ma and 0.95 and $0.7 \mathrm{Ma}$ would have been particularly dry. The permanency of the ATA Strombolian activity between 2.6 and 0.8 Ma suggests that the climatic conditions did not undergo sufficient variations to lead to changes in the eruptive dynamism. However, this seems unrealistic, especially as the climate has changed several times in Europe (three glacial and two interglacial episodes) during the same period. This apparent permanency may simply be the result of not having enough age determinations (12) and their lack of precision.

Although only two hydrovolcanic edifices have been dated, the ATA hydrovolcanic activity seems more recent $(610-500 \mathrm{ka})$ : it would have occurred during a period which corresponds in Europe to the Cromerian warm episode (Gunz-Mindel interglacial stage) that started $866 \mathrm{ka}$ ago and ended $478 \mathrm{ka}$ ago (Lisiecki and Raymo, 2007). There is a consensus among researchers that the European interglacial stages correspond to 


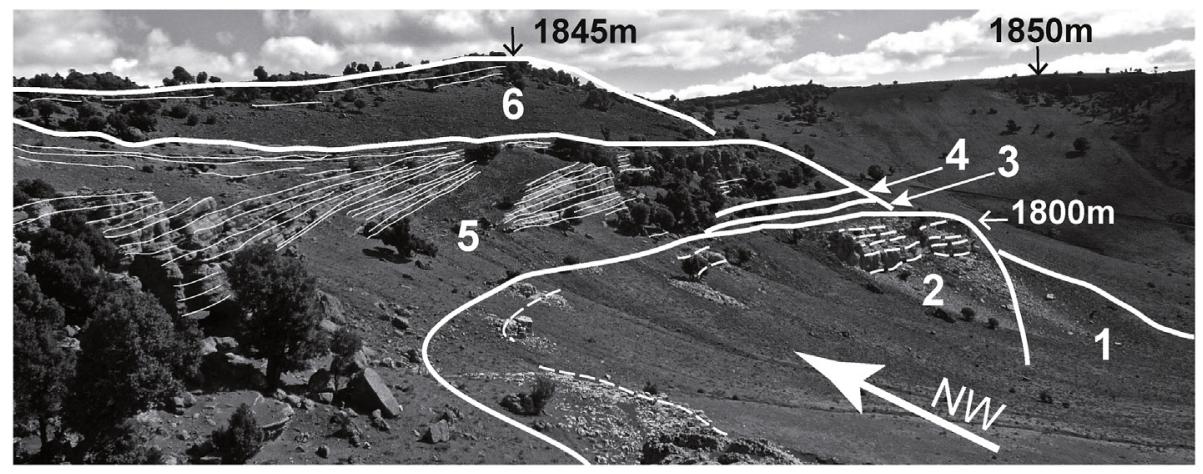

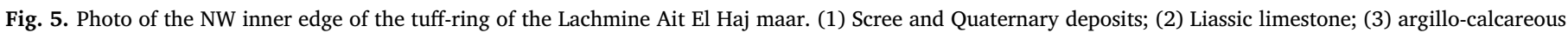
brownish loam ("terra rossa"); (4) Fall-out coarse breccia; (5) Dry surge deposits (tuff and lapilli-tuff); (6) Stombolian ejecta.

wet climatic periods in North Africa because of the intensification of monsoons and the progressive northwards migration of the monsoonal front (Su and Neelin, 2005; Jimenez, 2010; Sultan et al., 2015; Gaetani et al., 2017). According to Jimenez (2010) and Grant et al. (2017), the period between 0.65 and 0.4 Ma would have been dominated by wet stages. Therefore, the ATA hydrovolcanic activity would have occurred while the MA karst basement was abundantly supplied with water and probably saturated.

\subsection{Respective roles of epikarst and deep karst in hydrovolcanic dynamics}

If the prevailing wet conditions during the $610-500$ ka period explain the dominance of hydrovolcanism in the ATA, it does not explain the diversity of the hydrovolcanic dynamics and edifices observed here This diversity, which led us to distinguish four types of edifices, can be explained only if the hydrological functioning of the karst reservoirs beneath each type was specific at the time of eruption.

The edifices providing the most information on the functioning of the karst reservoirs seem to be those of Type 4. The detail study of one of them (Figs. 7 and 7 continued and Appendix 1 of Supplementary Material) shows that two lithofacies can be distinguished among the deposits of these edifices:

- The first one (represented in the Tafraoute section on Figures 7 and 7 continued) by units 5, 6, 7, 8, 10, 11, 12, 13, 20, 23, 26, 27, 29, 31 - also see Appendix 1 of Supplementary material) consists of finely stratified decimetric to metric series constituted by several tens of layers of (i) fine-grained, planar bedding, undulatory or dune- bedded tuff layers, with thicknesses comprised between 2 and $10 \mathrm{~cm}$, interbedded with (ii) unsorted or inversely graded bedded, massive or undulatory lapilli-tuff layers up to $30 \mathrm{~cm}$ thick. Scour-fill beddings and small channels are visible in many of these layers. None of the tuff layers contain accretionary lapilli, stoss-side accretion or plastering and they can be considered as deposits of dry pyroclastic density currents. A few coarser levels rich in ballistic bombs are dispersed among these tuffs and they can be seen as fallout deposits, but they represent less than $2 \%$ of the ejecta ring in terms of volume. Therefore, this lithofacies associates typical dry surge and fallout deposits from the co-surge plume. However, the scarcity and thinness of the fallout deposits suggest that, on the whole, the jets at the origin of this lithofacies were rather of low or medium energy. At Tafraoute, the deposits related to this lithofacies obtain a total thickness close to $6.5 \mathrm{~m}$ that represents one quarter of the ejecta in terms of volume. Moreover, they are largely dominant in the lower part of the section (units 5 to 13, with a cumulative thickness of $4.5 \mathrm{~m}$ ); then they appear as thinner series (between 30 and $50 \mathrm{~cm}$ thick), in the median and upper parts of the section, interbedded with layers of lithofacies 2. Photos of lithofacies 1 are given in Fig. 8a, b, c, e and $\mathrm{f}$.

- The second lithofacies (represented in the Tafraoute section on Figures 7 and 7 continued by units $9,14,15,16,17,18,19,21,22$, 24, 25, 28, 30, 32, 33 - also see Appendix 1 of Supplementary Material) consist of relatively thick matrix-supported breccia beds (between 30 and $150 \mathrm{~cm}$ thick) with characteristics of mud to debris flow deposits. These beds are also grouped in series that include up to ten beds. At Tafraoute, the thickness of this lithofacies reaches

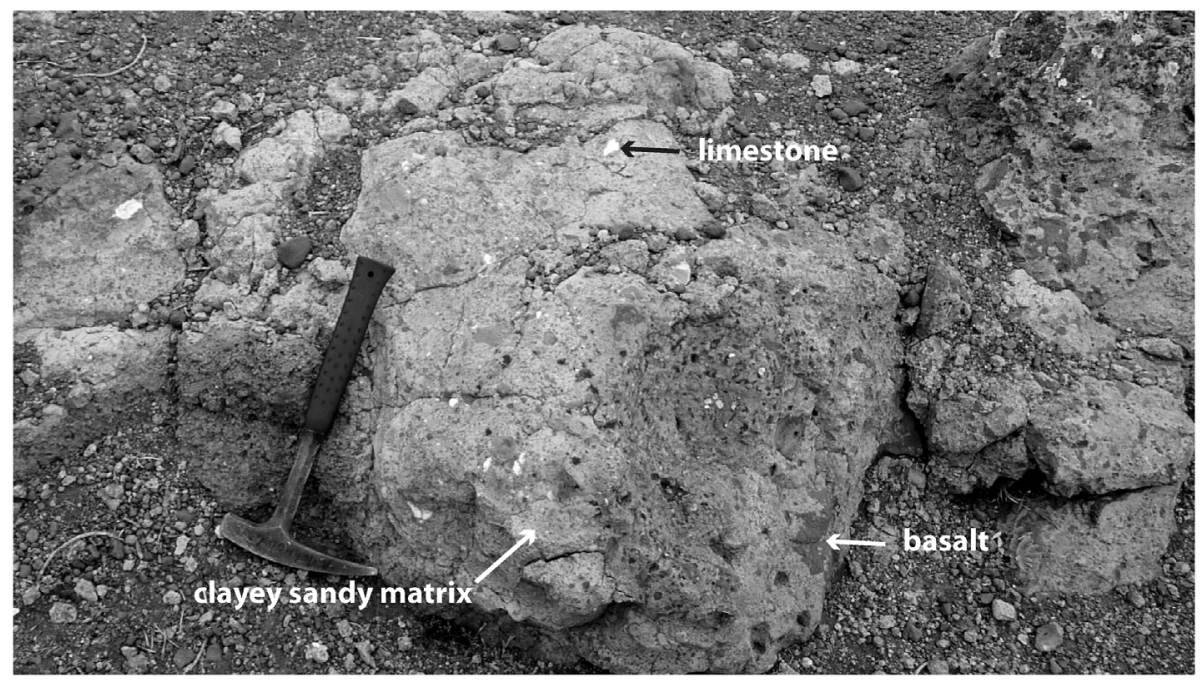

Fig. 6. Matrix-supported breccia bed (debris-flow) from the Lachmine Izyar ejecta embankment. 

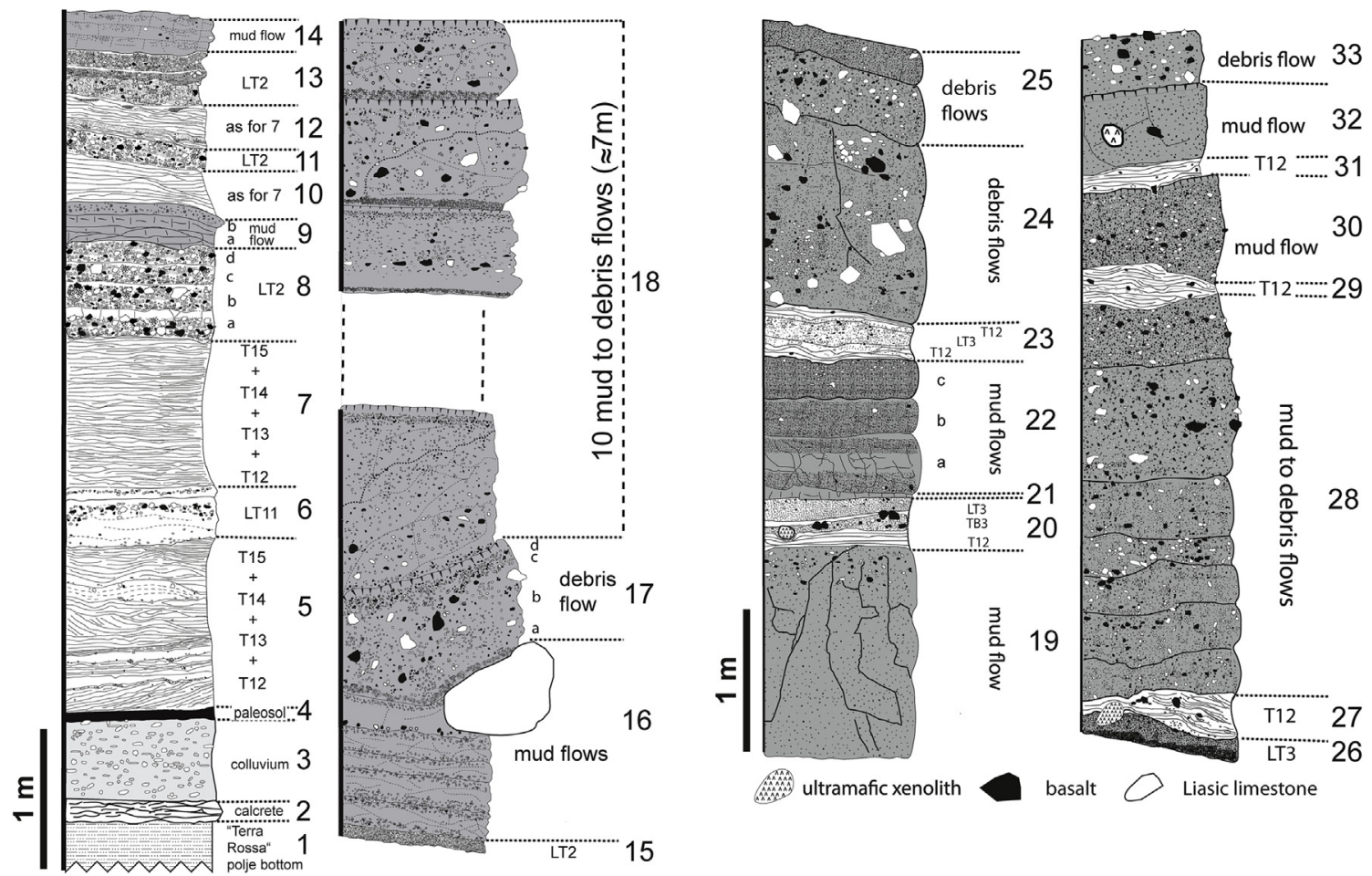

Fig. 7. Stratigraphic section of the eastern inner slope of the Tafraoute tuff-ring (section AB, Fig. 4.4).

In the following paragraphs, the numbers in parenthesis are the units distinguished in Fig. 7 and 7 continued and the index in brackets are their facies in the classification of Sohn and Chough (1989). For more information, see Appendix 1 of Supplementary Material.

(1) argillo-calcareous brownish loam corresponding to polje bottom ante-volcanic sediment (terra rossa) of unknown thickness.

(2) yellowish laminated and very indurated caliche around $15 \mathrm{~cm}$ thick.

(3) layer $60 \mathrm{~cm}$ thick of soft colluvium containing $30-40 \%$ of limestone debris $(\varnothing<5 \mathrm{~cm})$ dispersed in a beige-coloured argillo-carbonated-arenaceous matrix.

(4) $10 \mathrm{~cm}$ thick blackish organic matter-rich paleosoil, eroded by places but without any thermometamorphism trace.

The units 1 to 4 are free from any basaltic fragment.

(5) series, $1.2 \mathrm{~m}$ thick, consisting of about sixty alternating very thin to thin (centimetre-decimetre) beds of finely laminated beige tuff and of greyish lapilli-tuff containing up to $60 \%$ of clasts with diameters comprised between 1 and $2 \mathrm{~mm}$. In the lower beds, the lapilli are exclusively limestone granules, but the proportion (up to $20 \%$ ) and the size (up to $2,5 \mathrm{~cm}$ ) of basalt lapilli gradually increase towards the top of the series. The beds are either unsorted or slightly inversely sorted, sometimes planar-bedded (T12), generally low angle undulatory-bedded (T14) (wavelength between 3 and 4m, amplitude 10 cm) or dune-bedded (T15) with lee-side accretion, sometimes even scour-bedded (T6, LT6) and low angle cross-bedded. No accreted lapilli were observed. (Fig.8a).

(6) series consisting of two medium beds exhibiting weak undulations and inverse graded bedding (Fig.8b) (facies LT4, Sohn and Chough, 1989). More than 60\% of clasts are calcareous, the remaining $40 \%$ being basaltic: the first ones are always angular, sometimes flattened; the second ones are dark grey, most often polygonal and aphyric and non vesicular. The matrix is beige and of clayish-sand appearance as in (5). The first layer is weakly erosive on $(5)$. By places, thin $(\approx 2 \mathrm{~cm})$ whitish ultrafine-grained levels top these two layers.

(7) series $1.2 \mathrm{~m}$ thick consisting of about fifty centi- to decimetric layers of finely laminated tuff and lapilli-tuff displaying exactly the same characteristics and the same evolution from bottom to top as in the unit (5). The major difference is the presence of basalt lapilli from the first levels of this unit.

(8) series including four layers a, b, c, d (20,15, 10 and $15 \mathrm{~cm}$ thick, respectively) of lapilli-tuff, relatively matrix-poor (between 50 and $40 \%)$, rich in clasts of relatively big size (mean size around $5 \mathrm{~cm}$, up to $10 \mathrm{~cm}$ ) but always without bomb sag. (8a) is erosive on (7). Except for (8d), all are topped, as the layers (6), by whitish ultrafine-grained levels of a few $\mathrm{cm}$ thick. (8a) is disorganized (LT2) while b, c, d are inversely graded (LT4). (Fig.8c).

(9) series consisting of 2 fine-grained massive deposits (a) and (b). (9a), around $20 \mathrm{~cm}$ thick and of beige colour, fills erosion channels near $10 \mathrm{~cm}$ deep and a few meters large dug in (8): it contains less than $5 \%$ of basaltic and limestone granules always of size less than $3 \mathrm{~mm}$ and it displays internal laminations underlined by discontinuous gravels alignments and inducing lens-shaped jointing (Fig.8c). (9b) (10 cm thick) is light grey, more indurated than (9a) and it contains more clasts $(\approx 20 \%)$ of same size as $(9 \mathrm{a})$ and it is weakly inversely graded.

(10) series $40 \mathrm{~cm}$ thick consisting of about twenty tuff-layers of dry dilute base-surges tuffs similar to (5) and (7).

(11) layer about $20 \mathrm{~cm}$ thick of lapilli-tuff perfectly similar to (8d).

(12) new series, near $40 \mathrm{~cm}$ thick, of dry dilute base-surges tuffs identical to (10), (5) and (7).

(13) series, $\approx 40 \mathrm{~cm}$ thick, consisting of 3 layers of coarse lapilli-tuff enriched in basaltic clasts and inversely graded. The lowest layer is, at the same time, the thickest $(20 \mathrm{~cm}$ ) and the coarsest and its upper surface is hollowed by bomb sags several $\mathrm{cm}$ deep under glassy and polygonal bombs (up to $10 \mathrm{~cm}$ in diameter). The intermediate layer (around $10 \mathrm{~cm}$ thick), unlike the other two, can be described as a true grain-supported lapilli tuff: its drapes the sags observed in the underlying layer. The highest level is almost similar to the lowest.

(14) unit including 3 relatively thin muddy layers, around $10 \mathrm{~cm}$ thick each, of pinkish to brownish colour, poor (less than $20 \%)$ in small sized $(<0.5 \mathrm{~cm}$ in diameter) clast and weakly inversely graded. They are similar to (9b).

(15) decimetre layer of grain-supported tuff-breccia (TB1) essentially constituted of non-vesicular basalt polyhedral lapilli and fine blocks without any graded bedding.

(16) unit, around $80 \mathrm{~cm}$ thick, including four thin mud layers of similar thickness $(\approx 20 \mathrm{~cm})$ and showing clasts $(\varnothing<5 \mathrm{~cm})$ concentrations both at their top and base. The higher layer surrounds an abnormally large boulder $(1.6 \times 1.3 \mathrm{~m})$ of the same chert-rich limestone in which the crater is dug. This boulder can be only result from the inward collapse of the crater eastern edge.

(17) unit consisting of an only one, $1.2 \mathrm{~m}$ thick, massive and highly indurated layer that wraps the large underlying boulder. It can be divided into 4 levels (from bottom to top, 17a, b, c and d). (17b), a typical matrix supported breccia including about $30 \%$ clasts (up to $20 \mathrm{~cm}$ in diameter) and without any graded bedding, corresponds to the major part of layer $(\approx 70 \mathrm{~cm})$; at its base (17a) and at its top (17c), two levels of concentration in clasts $(\varnothing<5 \mathrm{~cm})$, around $20 \mathrm{~cm}$ thick each, are 
visible; finally (17d) a muddy decimetre level displaying cracks through its entire thickness and corresponding probably to a settling deposit, caps this layer.

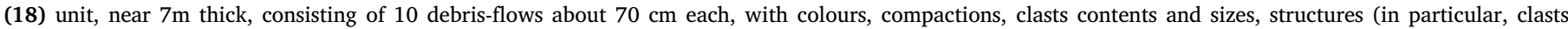

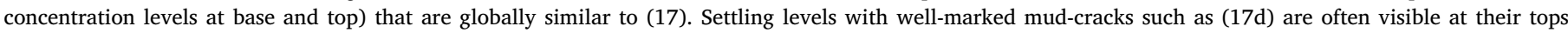
(Fig. 8d).

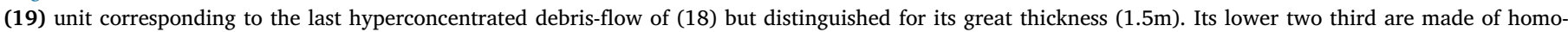

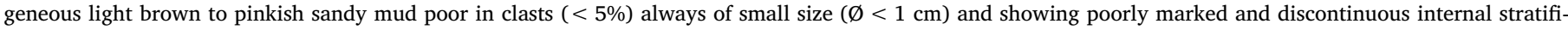

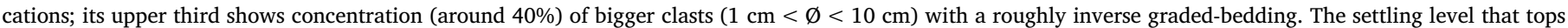

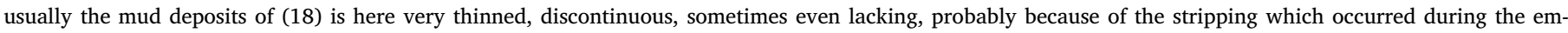
placement of (20).

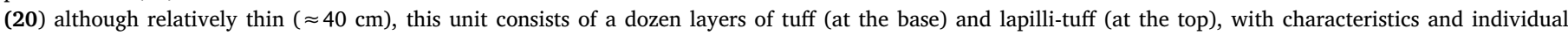

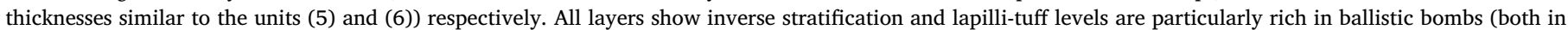
limestone, basalt, granulite and peridotite), sometimes large (up to $15 \mathrm{~cm}$ in diameter) and with well-marked sags under them.

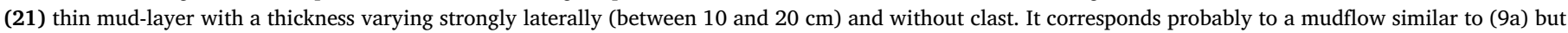
partly eroded by the overlying deposits.

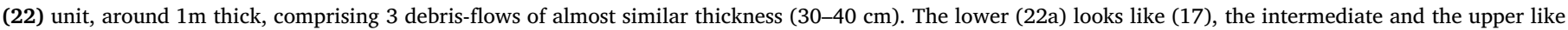
(18).

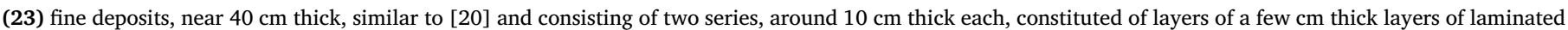
beige tuff without ballistic bomb, separated by a black lapilli-tuff layer $20 \mathrm{~cm}$ thick.

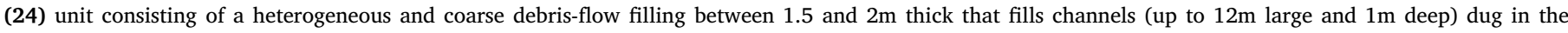

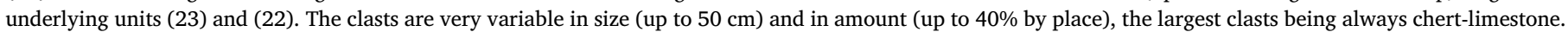
This flow does show neither sorting nor settling level at its top.

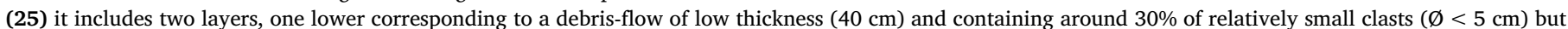
with a slight inverse graded bedding and one upper corresponding to a thin homogeneous mudflow ( $30 \mathrm{~cm})$ almost exempt of clast and without any sorting.

(26) layer, around $10 \mathrm{~cm}$ thick, of lapilli-tuff essentially constituted of non-vesicular cm-sized basaltic clasts, without any graded bedding (LT2).

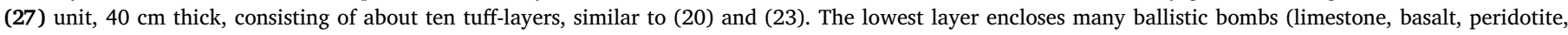
granulite) sometimes of very large size (up to $30 \mathrm{~cm}$ ) with deep bomb sags, as in (23).

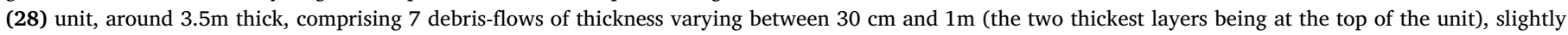
channelled and containing around $40 \%$ of clasts $(\varnothing<20 \mathrm{~cm})$. Neither sorting, nor settling level were observed in these flows, as for $(24)$.

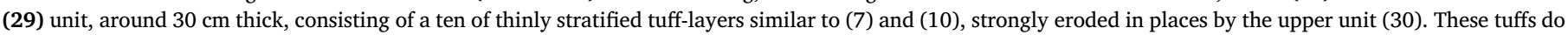
not contain ballistic bomb.

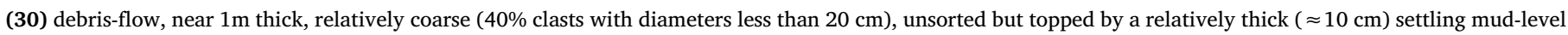
with well-marked mud cracks (Fig. 8e).

(31) unit, $\approx 30 \mathrm{~cm}$ thick, consisting of a dozen of thinly cross-stratified tuff-layers (Fig.8f) perfectly similar to (29).

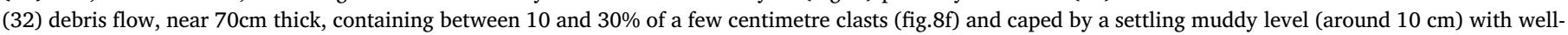

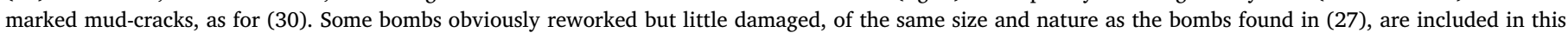
formation.

(33) last debris-flow of section. It is near $30 \mathrm{~cm}$ thick and similar to debris flows (28).

around $20 \mathrm{~m}$, i.e. three times higher than the lithofacies 1 , and it largely dominates in the upper four fifths of the section. Such hyperconcentated deposits are generally attributed to a phreatomagmatic wet surge or lacustrine activity. However, in the case of the studied edifices, all of the features classically attributed to wet surges, such as accretionary lapilli, stoss-side accretion and plastering, are lacking. Some flows are massive and without sorting, whereas others display light inverse graded bedding, sometimes associated with marks of tractional transport. Moreover, many are capped by settling clay levels that are several $\mathrm{cm}$ thick with wellmarked mud cracks. Photos of lithofacies 2 are given in Fig. 8c, d, e and $\mathrm{f}$.

The course of a Type 4 eruption could be explained by interaction of magma with variable amounts of water. The water supply would be rhythmic but it would increase over time and it would be combined with a rise to the surface of magma in successive batches of volume decreasing over time. Lithofacies 1 (dry base surge and fall out deposits) is the result of an interaction between ascending magma and a small amount of water. The ascending magma would first reach the lower part of the deep karst aquifer where the water content is rather low, since the primary porosity of dolomitic limestones is generally lower than 20\% (Manger, 1963) and the secondary porosity (karst features), also referred to as effective porosity, generally does not exceed 2-3\% (Vacher and Mylroie, 2002; Fleury et al., 2009; Jourde et al., 2014). The explosions at the origin of the lithofacies 1 would have been generated at this level and the craters of Type 4 edifices would have been excavated during this first explosive cycle. The shallow depth (between 10 and $30 \mathrm{~m}$ deep) of these craters suggests that the deep karst aquifer was relatively close to the surface and that, under these conditions, the deep karst and the epikarst were perhaps very close to each other. As these first phreatomagmatic activity decreased in intensity, probably due to a smaller magma influx, these craters were probably invaded by water due to the drainage of the water stored in the surrounding epikarst. Temporary shallow ponds may have even settled at their bottoms. A similar trend has already been described for monogenic volcanic complex of Mount Gambier in Australia (Van Otterloo et al., 2013). In these new conditions, the interaction between the small amounts of magma still rising to the surface and water would occur at the bottom of the flooded craters. The standing water body was not deep enough to trigger a Surtseyan style eruption. Violent explosive jets would therefore no longer be produced, but the magma-water interaction was strong enough to produce mud and debris flows, which spread on the flanks of the growing tuff rings. However in all Type 4 edifices, this relatively quiet activity was followed by new cycles of phreatovolcanic explosions and by new deposits of lithofacies 1 , as illustrated by Figures 7 and 7 continued. Crater emptying was probably the consequence of the arrival of a new magma batch. In the case of the largest Type 4 tuff rings, this succession of events would have been repeated several times (eight times at Tafraoute) during the eruption. Given the small quantities of basalt in both the tuffs of lithofacies 1 and the mud and debris flows of lithofacies 2, the successive magma batches reaching the surface were probably of small volume. However, the presence of xenoliths of peridotite and lower crust up to $30 \mathrm{~cm}$ in diameter in some fallout layers indicates that the ascent speeds of these batches, in spite of their low volume, were sometimes quite high.

Type 1 maars are very rare in the ATA. Their depths (for instance $55 \mathrm{~m}$ at Lachmine Ait El Haj) show that the interaction between the ascending magma and water took place at greater depths than for Type 4. They are all located to the north of the district, in an area where the 

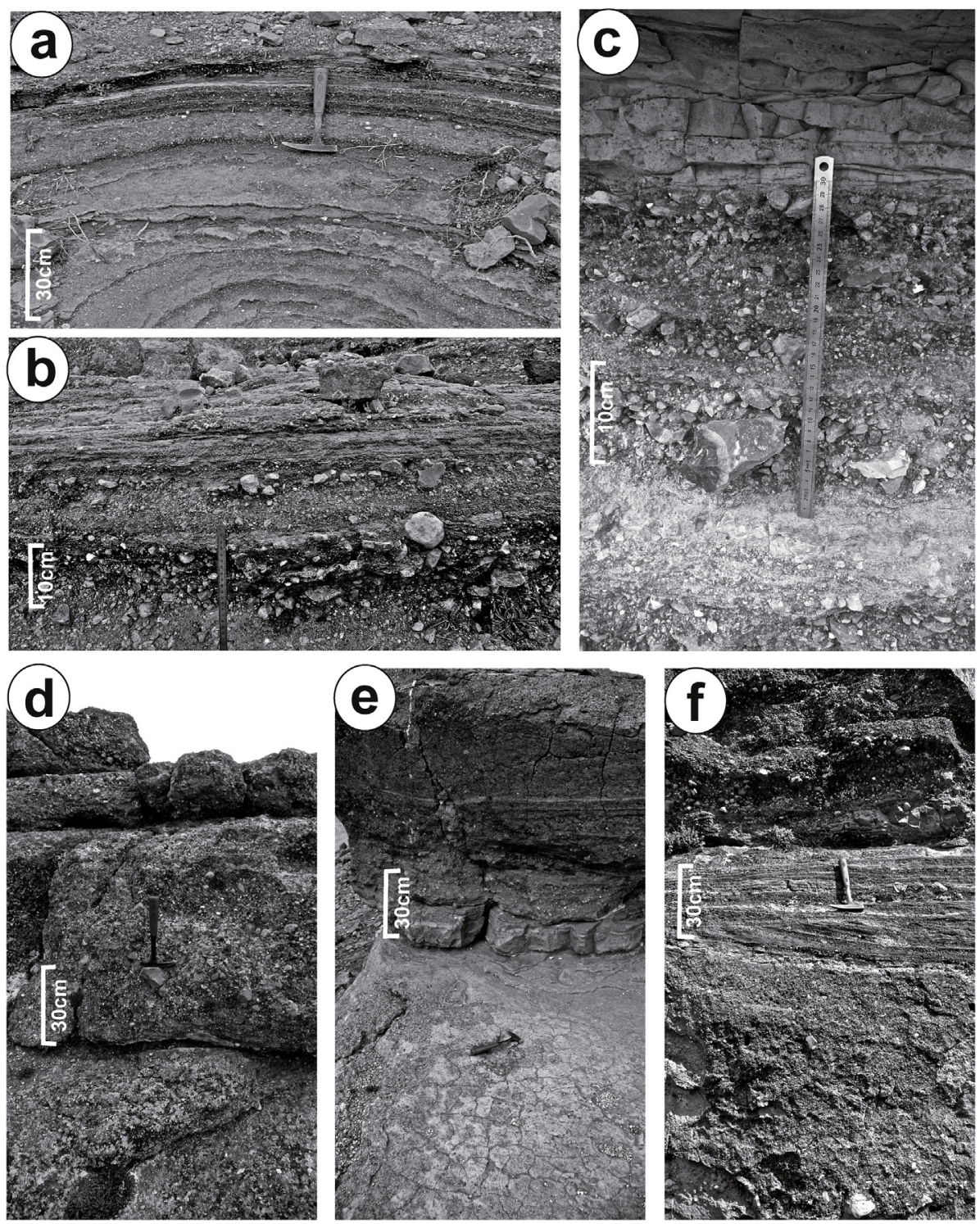

Fig. 8. Photos of some ejecta beds from the Tafraoute tuff-ring. The numbers between brackets correspond to the units defined in Fig.7 and 7 continnued. $\mathbf{a}=$ First volcanic deposits consisting of fine-grained and laminated tuffs (5); $\mathbf{b}=$ Inverse graded bedding in dry surge lapilli-tuff beds (6); $\mathbf{C}=$ Transition between lapilli-tuffs (8) and massive lens-shaped jointed mud layer (9); $\mathbf{d}=$ Beds of matrix-supported coarse breccia corresponding to one of the ten debris flows of (18); e = Transition between the debris-flow (30) (which is toped by a settling mud-level with mud-cracks) and the dry surge tuff of unit (31); $\mathbf{f}=$ Transition between the dry surge tuff levels (31) and the debris flow (32). Note the crossstratification in (31). basement altitudes are higher than $1800 \mathrm{~m}$ : in this case, the roof of the deep karst is probably located at a greater depth than for Type 4. Most deposits can be described as dry base surge tuffs, lapilli-tuffs or fallout breccia. However, as evidenced by the intercalation of some levels of mud or debris flows around $50 \mathrm{~cm}$ thick among the surge deposits, the bottom of the crater may have sometimes been invaded by water, but only briefly. This observation suggests that, although the main watermagma interaction took place at the deep karst level, the volcanic dynamism seems to have been modified several times by brief influxes of water from the surrounding epikarst.

The eruptions that produced the Type 2 edifices, such as Ain Touna, probably took place where the surface water storage was very high, possibly at the bottom of dolines or poljes permanently invaded by water. These karst depressions were probably fed by a continuous emptying of the neighbouring water-saturated epikarsts, but the water sheet at their bottoms remained relatively thin during the eruptions. The explosions were rhythmic and always of low energy. This is consistent with the very shallow depth of their craters $(5 \mathrm{~m})$ and their tuff rings made entirely of mud and debris flows.

A single edifice, Lachmine Izyar, represents Type 3. Its tuff-embankment is quite similar to that of Type 2, at least as regards the nature and structure of the deposits. Indeed, this embankment borders an impressive crater ( $1.4 \mathrm{~km}$ long, $600 \mathrm{~m}$ wide, $80 \mathrm{~m}$ deep), which has a volume about ten times greater than the volume estimated for tuffs. This suggests that the Lachmine Izyar crater is not of explosive origin: it probably existed before the eruption and it was certainly a large collapsed depression of karst origin.

\subsection{Relationships between hydrovolcanism, spacing between epikarst and deep karst and topography}

We have observed that the Type 4 tuff rings are clustered in a small $\left(\approx 20 \mathrm{~km}^{2}\right)$ depressed zone $(1,700-1,750 \mathrm{~m})$ in SE quarter of the ATA (Fig. 2), whereas the Type 1 maars are distributed into an arc-shaped zone approximately $10 \mathrm{~km}$ long, of higher altitude (between 1800 and $1900 \mathrm{~m}$ ) and located upstream of the depressed zone (Fig. 2). During the Pleistocene wet periods, the depressed zone probably had a different hydrogeological behaviour compared to the surrounding plateau and it played a major role in rainwater storage and drainage. The spacing between the water saturated deep karst and the epikarst was probably small here and the epikarst was probably also characterized by a very high degree of saturation in water. This could explain the important role of epikarst in the dynamics of the Type 4 eruptions and the clustering of Type 4 edifices in a depressed zone. In contrast, the epikarst of the zones of higher altitude was probably drained towards the depression and consequently the infiltration zone between the 


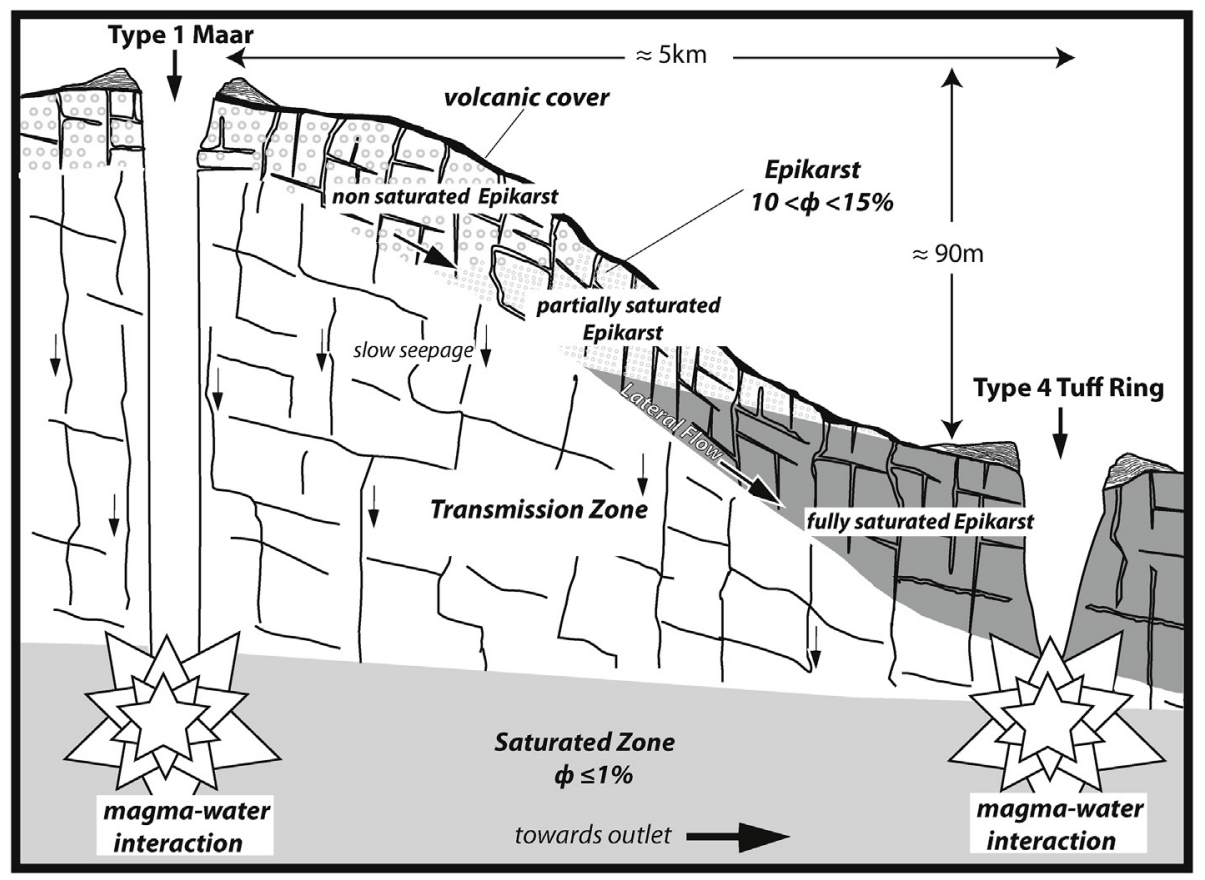

Fig. 9. Hypothetical interpretative scheme showing the position of the water-magma interaction zones with respect to the different compartments of karst in the case of maars (Type 1 ) and in the case of Type 4 tuff-rings. $\Phi=$ porosity.

saturated deep karst and the epikarst was thick and relatively dry, even during wet periods. This configuration could explain the prevailing role of the saturated deep karst and the minor role of the epikarst in the eruptions at the origin of the Type 1 maars. A hypothetical interpretative scheme showing the position of the water-magma interaction zones with respect to the different compartments of the karst in the case of the maars (Type 1) and the Type 4 tuff rings is proposed in Fig. 9.

The area where the Type 2 and 3 tuff rings are located (Fig. 2) has the same altitude as the area of Type 1 Maars $(1850-1900 \mathrm{~m})$, but it is characterized by the presence of numerous collapsed cavities (caprock dolines) and mounds of limestone emerging from the basalt cover (Figs. 1c and 2). This peculiar landscape suggests that the volcanic cover here is rather thin and that the dissolution of the underlying limestone is very important. During the Pleistocene wet periods, the surface of this area was certainly dotted with ponds and marshes, and many of the volcanic eruptions that occurred here were probably controlled by an interaction of magma with surface waters.

\section{Conclusions}

In conclusion, we can say that the shift from the predominantly Strombolian activity to the entirely hydrovolcanic activity observed in the ATA corresponds to a climatic change from dry to wet that would have taken place between 800 and $610 \mathrm{ka}$ and that has continued until at least $500 \mathrm{ka}$ ago.

In the other hand, this work shows that the ATA is a particularly suitable site for evaluating the interaction between water and magma in a karst setting. In particular, it highlights the variability of the mechanisms involved in the edification of the tuff rings in relation with the respective roles of the deep karst and epikarst during the eruptions. This study suggests that the most important factor in determining the roles of these two karst compartments is their relative spacing (infiltration zone thickness). This spacing depends not only on the climatic conditions prevailing at the time of the eruptions but also on the location of the eruptive sites with respect to the topography of the limestone substratum beneath the volcanic cover.

These conclusions are in perfect agreement with several recent studies carried out elsewhere in various resolutions (Kereszturi et al.,
2011; Nemeth et al., 2012; Kshirsagar et al., 2015, 2016), which also showed that intra-plate volcanism can be strongly influenced, not only by the availability of water from surface (which of course depends on climatic conditions), but also by the hydrogeological context of the region.

\section{Acknowledgements}

This study was performed as part of a collaborative multi-disciplinary research project on volcanism and Upper mantle petrology of Middle Atlas (Northern Morocco) involving the Faculty of Sciences of Meknes (University Mouldy Ismail, Morocco) and Geosciences Montpellier (CNRS \& University of Montpellier, France). Funding for research was provided by CNRS (INSU and DERCI, France), CNRST (Morocco), the French Ministry of Foreign Affairs (MAE), and the European FP7 'Marie Curie' program, through the CNRS-CNRST bilateral cooperation project \#24499 (2010-2012), the MAE cooperation project \#042/STU/09 in the frame of the "Solubilise Hubert Curie" program (2010-2013), three INSU research grants ("Actions Cordoned" 2008, and SYSTER 2010 and 2011), and the FP7-PEOPLE-2013- IRSES project MEDYNA (Maghreb-Au research staff exchange on geodynamics, geohazards, and applied geology in Northwest Africa 2014-2017, VP3 - Deep structures and mantle processes). We thank A. Lemmolo for his technical support during ${ }^{40} \mathrm{Ar} /{ }^{39} \mathrm{Ar}$ analyses. We thank Pr. Németh and Youbi for their corrections and constructive remarks.

\section{Appendix A. Supplementary data}

Supplementary data to this article can be found online at https:// doi.org/10.1016/j.jafrearsci.2020.103845.

\section{References}

Abdelmounji, A., Remmal, T., El kamel, F., El Amarani El Hasssani, I., Van Wyk de Wries, B., Boivin, P., 2019. Geomorphological classification and landforms inventory of the middle-atlas volcanic province (Morocco): scientific value and educational potential. Quaest. Geogr. 38 (1), 107-129.

Agustin-Flores, J., Nemeth, K., Cronin, S.J., Lindsay, J.M., Kereszturi, G., Brand, B.D. Smith, I.E.M., 2014. Phreatomagmatic eruptions through unconsolidated coastal 
plain sequences, Maungataketake, Auckland Volcanic Field (New Zealand). J. Geotherm. Res. 276, 46-63.

Agustin-Flores, J., Nemeth, K., Cronin, S.J., Lindsay, J.M., Kereszturi, G., 2015. Construction of the north head (maungauika) tuff cone: a product of surtseyan volcanism, rare in the auckland volcanic field, New Zealand. Bull. Volcanol. 77 (2), $1-17$.

Aranda Gomez, J.J., Luhr, J.F., 1996. Origin of the joya honda maar, san luis potosi, Mexico. J. Volcanol. Geoth. Res. 74, 1-18.

Balogh, K., Nemeth, K., 2005. Evidence for the neogene small-volume intracontinental volcanism in western Hungary: K/Ar geochronology of the Tihany Maar volcanic complex. Geol. Carpathica 56 (1), 91-99.

Bentayeb, A., Leclerc, C., 1977. Le Causse moyen atlasique. In: Ressources en eaux du Maroc, 3, Domaines Atlasiques et Sud-Atlasiques. Notes et Mémoires du Service Géologique du Maroc, vol. 231. pp. 37-66.

Bosch, D., Maury, R., El Azzouzi, M., Bollinger, C., Bellon, H., Verdoux, P., 2014. Lithospheric origin for Neogene-Quaternary Middle Atlas lavas (Morocco): clues from trace elements and Sr-Nd-Pb-Hf isotopes. Lithos 205, 247-265.

Brand, B.D., White, C.M., 2007. Origin and stratigraphy of phreatomagmatic deposits at the Pleistocene sinker butte volcano, western snake river plain, Idaho. J. Volcanol. Geoth. Res. 160 (3), 319-339.

Brand, B.D., Clarke, A.B., Semken, S., 2009. Eruptive dynamics and depositional processes of Narbona Pass maar volcano, Navajo volcanic field, Navajo Nation, New Mexico (USA). Bull. Volcanol. 71 (1), 49-77.

Cas, R.A.F., Wright, J.V., 1988. Volcanic Successions Modern and Ancient. https://doi. org/10.1007/978-94-009-3167-1-4.

Charrières, A., 1985. Les grands traits de l'évolution mésozoïque de la couverture du Moyen Atlas central. 110e Cong. Nat. Soc. Savantes, Montpellier, pp. 268.

DeMenocal, P.B., 2004. African climate change and faunal evolution during the PliocenePleistocene. Earth Planet Sci. Lett. 220, 3-24.

Duggen, S., Hoernle, K., Hauff, F., Klugel, A., Bouabdellah, M., Thirlwall, M., 2009. Flow of Canary mantle plume material through a subcontinental lithospheric corridor beneath Africa to the Mediterranean. Geology 37, 283-286. https://doi.org/10. $1130 / \mathrm{G} 25426 \mathrm{~A}$.

El Arabi, H., 1987. Etude stratigaphique et sédimentologique du Lias aux confins du Causse Moyen Atlasique et du Moyen Atlas Plissé (Maroc). - Thèse $3^{\mathrm{e}}$ cycle. Univ. Toulouse, pp. 199.

El Azzouzi, M., Maury, R.C., Bellon, H., Youbi, N., Cotten, J., Kharbouch, F. 2010. Petrology and K-Ar chronology of the neogene-quaternary middle atlas basaltic province, Morocco. Bull. Soc. Géol. France 181, 243-257.

El Jihad, M.D., 2016. Climate change and rural development in the middle atlas mountains and fringe areas (Morocco). J. Alp. Res. https://doi.org/10.4000/rga.3465. $104-4$

El Messbahi, H., Bodinier, J.-L., Vauchez, A., Dautria, J.-M., Houali, O., Garrido, C.J., 2015. Short wavelength lateral variability of lithospheric mantle beneath the Middle Atlas (Morocco) as recorded by mantle xenoliths. Tectonophysics 650, 34-52.

Fedan, B., 1988. Evolution géodynamique d'un bassin intraplaque sur décrochements (Moyen Atlas, Maroc) durant le Méso-Cenozoique. Thèse Doctorat, Univ. Mohammed V, Rabat, pp. 338

Fedan, B., Laville, E., El Mezgueldi, A., 1989. Le bassin jurassique du Moyen Atlas (Maroc) : exemple de bassin sur relais de décrochernents. Bull. Soc. Geol. France 8 (6), 1123-1136.

Fisher, R.V., 1966. Rocks composed of volcanic fragments. Earth Sci. Rev. 1, 287-298.

Fisher, R.V., 1979. Models for pyroclastic surges and pyroclastic flows. J. Volcanol. Geoth. Res. 6, 305-318.

Fisher, R.V., Schmincke, H.U., 1984. Pyroclastic Rocks. Springer, Heidelberg, pp. 474.

Fleury, P., Ladouche, B., Conroux, Y., Jourde, H., Dörfliger, N., 2009. Modelling the hydrologic functions of a karst aquifer under active water management - the Lez spring. J. Hydrol. 365 (3-4), 235-243.

Frison de Lamotte, D., Zizi, M., Missenard, Y., Hafid, M., Azzouzi, M.E., Maury, R.C., Charrière, A., Taki, Z., Benammi, M., Michard, A., 2008. In: Michard, A., Saddiqi, O., Chalouan, A., Frison de Lamotte, D. (Eds.), Continental Evolution: the Geology of Morocco. Springer Berlin Heidelberg, pp. 133-202.

Gaetani, M., Messori, G., Zhang, Q., Flamant, C., Pausata, F.S.R., 2017. Understanding the Mechanisms behind the Northward Extension of the West African Monsoon during the Mid-holocene. https://doi.org/10.1175/JCLI-D-16-0299.1.

Grant, K.M., Rohling, E.J., Westerhold, T., Zabel, M., Heslop, D., Konijnendijk, T., Lourens, L., 2017. A 3 million year index for North African humidity/aridity and the implication of potential pan-African humid periods. Quat. Sci. Rev. 171, 100-118. https://doi.org/10.1016/j.quascirev.2017.07.005.

Harmand, C., Cantagrel, J.M., 1984. Le volcanisme alcalin Tertiaire et Quaternaire du Moyen Atlas (Maroc): chronologie K/Ar et cadre géodynamique. J. Afr. Earth Sci. 2, $51-55$.

Heiken, G.H., 1974. An atlas of volcanic ash. Smithsonian Earth Science Contributions 12, $1-101$.

Jacob, T., Bayer, R., Chery, J., Jourde, H., Le Moigne, N., Boy, J.P., Hinderer, J., Luck, B., Brunet, P., 2008. Absolute Gravity monitoring of water storage variation in a karst aquifer on the larzac plateau (Southern France). J. Hydrol 359, 105-117.

Jimenez, G., 2010. Travertine from Egypt's Western Desert: a Terrestrial Record of North African Paleohydrology and Paleoclimate during the Late Pleistocene. hp:// digitalrepository.unm.edu/eps_etds/41.

Jourde, H., Lafare, A., Mazzilli, N., Belaud, G., Neppel, L., Doerfliger, N., Cernesson, F. 2014. Flash flood mitigation as a positive consequence of anthropogenic forcings on the groundwater resource in a karst catchement. Environmental Earth Sciences 71, 573-583.

Kereszturi, G., Nemeth, K., Csillag, G., Balogh, K., Kovacs, J., 2011. The role of externa environmental factors in changing eruption styles of monogenetic volcanoes in a Mio/Pleistocene continental volcanic field in western Hungary. J. Volcanol. Geoth. Res. 201 (1-4), 227-240.

Kharbouch, F., 2010. Petrology and K-Ar chronology of the neogene- quaternary middle atlas basaltic province, Morocco. Bull. Soc. Géol. France 181, 243-257 1810.2113/ gssgfbull.181.3.243.

Kshirsagar, P., Siebe, C., Guilbaud, M.N., Salinas, S., Layer, P.W., 2015. Late Pleistocene Alberca de Guadalupe maar volcano (Zacapu basin, Michoacan): stratigraphy, tectonic setting, and paleo-hydrogeological environment. J. Volcanol. Geoth. Res. 304, 214-236.

Kshirsagar, P., Siebe, C., Guilbaud, M.N., Salinas, S., 2016. Geological and environmental controls on the change of eruptive style (phreatomagmatic to Strombolian-effusive) of Late Pleistocene El Caracol tuff cone and its comparison with adjacent volcanoes around the Zacapu basin (Michoacan, Mexico). J. Volcanol. Geoth. Res. 318, 114-133.

Lakroud, K., Remmal, T., El Amrani, I., Mountaj, S., El Kamel, F., Van Wyk de Vries, B., Boivin, P., Balcone-Boissard, H., Makhoukhj, S., Soufi, M., 2019. Monogenetic strombolian activity at aguelmane sidi ali volcano (middle atlas volcanic province, Morocco. Geogr. Bull. 60 (2), 109-125.

Lisiecki, L.E., Raymo, M.E., 2007. Plio-Pleistocene climate evolution: trends and transitions in glacial cycle dynamics. Quat. Sci. Rev, 26 (1-2), 56-69.

Lorenz, V., 1986. On the growth of maars and diatremes and its relevance to the formation of tuff rings. Bull. Volcanol. 48, 265-274.

Lorenz, V., 1987. Phreatomagmatism and its relevance. Chem. Geol. 62 (1-2), 149-156.

Lorenz, V., 2003. Maar-diatreme volcanoes, their formation, and their setting in hardrock or soft-rock environments. Geolines 15, 72-83.

Manger, G.E., 1963. Porosty and bulk density of sedimentary rocks. Geol. Surv. Bull. 1114-E.

Missenard, Y., Zeyen, H., Frizon de Lamotte, D., Leturmy, P., Petit, C., Sébrier, M., Saddiqi, O., 2006. Crustal versus asthenospheric origin of relief of the Atlas Mountains of Morocco. J. Geophys. Res. 111, B03401. https://doi.org/10.1029/ 2005JB003708.

Murcia, H., Nemeth, K., El-Masry, N.N., Lindsay, J.M., Moufti, M.R.H., Wameyo, P., Cronin, S.J., Smith, I.E.M., Kereszturi, G., 2015. The Al-Du'aythah volcanic cones, AlMadinah City; implications for volcanic hazards in northern Harrat Rahat, Kingdom of Saudi Arabia. Bull. Volcanol. 77 (6), 19.

Németh, K., Martin, U., Harangi, Sz, 2001. Miocene phreatomagmatic volcanism at tihany (pannonian basin, Hungary). J. Volcanol. Geoth. Res. 111, 111-135.

Nemeth, K., Cronin, S.J., Smith, I.E.M., Flores, J.A., 2012. Amplified hazard of smallvolume monogenetic eruptions due to environmental controls, Orakei Basin, Auckland Volcanic Field, New Zealand. Bull. Volcanol. 74 (9), 2121-2137.

Németh, K., Kereszturi, G., 2015. Monogenetic volcanism: personal views and discussion. Int. J. Earth Sci. 104 (8), 2131-2146.

Németh, K., Szabolcs, K., 2020. Review of explosive hydrovolcanism. Geosciences 10 (2), 44. https://doi.org/10.3390/geosciences10020044.

Smith, I.E.M., Nemeth, K., 2017. Source to surface model of monogenetic volcanism; a critical review. Spec. Publ. Geol. Soc. Lond. 446 (1), 1-28. https://doi.org/10.1144/ SP446.14.

Sohn, Y.K., Chough, S.K., 1989. Deposititional processes of the suwulbong tuff ring, cheju island (korea). Sedimentology 36, 837-855.

Su, H., Neelin, J.D., 2005. Dynamical Mechanisms for African Monsoon Changes during the mid-Holocene. https://doi.org/10.1029/2005JD005806.

Sultan, A.M.B., Emil, M., Abotalib, Z.A., Abouelmagd, A., Alzahrani, A., Refai, A., AlQthamy, K., Alaamry, M., 2015. Nature and Timing of the Quaternary Wet Climatic Periods in North Africa and Arabia: Isotopic, Chronologic and Remote Sensing Constraints, vol. 47. Geological Society of America Abstracts with Programs, pp. 667.

Thorarinsson, S., Einarsson, Th, Sigvaldason, G.E., Eliasson, G., 1964. The submarine eruption off the Westmann Islands 1963-64, a preliminary report. Bull. Volcanol. 27 435-446.

Vacher, H.L., Mylroie, J.E., 2002. Eogenetic karst from the perspective of an equivalent karst medium. Carbonates Evaporites 17, 182-196.

Van Otterloo, J., Cas, R.A.F., Sheard, M.J., 2013. Eruption processes and deposit characteristics at the monogenetic Mt. Gambier Volcanic Complex, SE Australia: implications for alternating magmatic and phreatomagmatic activity. Bull. Volcanol. 75, 737.

White, J.D.L., Ross, P.S., 2011. Maar-diatreme volcanoes: a review. J. Volcanol. Geoth. Res. 201, 1-29.

Williams, P.W., 2008. The role of the epikarst in karst and cave hydrogeology: a review. International J.of Speleology 37, 1-10.

Wohletz, K.H., McQueen, R.G., 1984. Experimental studies of hydromagmatic volcanism. In: Explosive Vocanism: Inception, Evolution and Hazards. in: Geophysics. National Academy Press, Washington, D.C., pp. 158-169. 